\title{
Penerapan Terapi Generalis SP 1-4 Dengan Masalah Harga Diri Rendah Kronis Pada Penderita Skizofrenia
}

\author{
*Inri Sihombing ${ }^{1}$, Jesika Serevin Silitonga ${ }^{2}$, Juliana Simanjuntak ${ }^{3}$, \\ Khairunnisa Tanjung ${ }^{4}$, Jek Amidos Pardede ${ }^{5}$ \\ *inrisihombing06@gmail.com
}

\section{BAB 1}

\section{PENDAHULUAN}

\subsection{Latar Belakang}

Skizofrenia merupakan suatu gangguan jiwa berat yang bersifat kronis yang ditandai dengan ganggguan komunikasi, gangguan realitas (halusinasi atau waham), afek tidak wajar atau tumpul, gangguan fungsi kognitif serta mengalami kesulitan dalam melakukan aktivitas sehari-hari (Pardede, 2019). Salah satu gejala negative dari skizofrenia adalah perubahan perubahan perilaku individu yang mana selalu menilai diri dan orang lain secara negative, atau menilai rendah terhadap kemampuan yang dimilikinya yang disebut harga diri rendah (Rokhimmah, 2020).

Skizofrenia mempengaruhi sekitar 24 juta orang atau 1 dari 300 orang $(0,32 \%)$ di seluruh dunia. Angka ini adalah 1 dari 222 orang $(0,45 \%)$ di antara orang dewasa. Ini tidak umum seperti banyak gangguan mental lainnya. Onset paling sering selama masa remaja akhir dan dua puluhan, dan onset cenderung terjadi lebih awal di antara pria daripada di antara wanita (WHO, 2022). Cakupan pengobatan penderita gangguan skizofrenia/psikosis, 2018 yang berobat $84,9 \%$, tidak berobat $15,1 \%$, minum obat rutin $48,9 \%$, tidak rutin $51,1 \%$. Alasan tidak minum obat 1 bulan terakhir yang terbanyak merasa sudah sehat $36,1 \%$ dan terendah obat yang tidak tersedia 2,4\% (Tuasikal, 2019).. 
Gejala positif skizofrenia yaitu delusi, halusinasi. Gejala negatif dari skizofrenia yaitu apatis, afek datar, hilangnya minat atau ketidakmampuan untuk melakukan aktivitas rutin, kemiskinan isi pembicaraan, gangguan dalam 
hubungan sosial, tanda-tanda ini juga ditemukan pada pasien dengan harga diri rendah (Rahayu, 2019). Harga diri rendah kronis merupakan salah satu masalah keperawatan skizofrenia, karena harga diri rendah merupakan gejala negative dari skizofrenia (Pardede, 2020). Harga diri merupakan suatu penilaian diri terhadap hasil yang dicapai dengan menganalisis seberapa jauh perilaku memenuhi ideal diri frekuensi pencapaian tujuan akan menghasilkan harga diri yang rendah atau harga diri yang tinggi (Anggit, 2017). Harga diri rendah adalah perasaan negatif terhadap dirinya sendiri menyebabkan kehilangan rasa percaya diri, pesimis, dan tidak berharga di kehidupan (Atmojo, 2021).

Harga diri yang rendah yang dialami seseorang selama lebih dari 3 bulan merupakan harga diri rendah situasional. Sedangkan jika harga diri rendah yang dialami seseorang lebih dari 6 bulan merupakan harga diri rendah kronik yang harus segera ditindak lanjuti. Dampak dari seseorang yang memiliki harga diri rendah akan berisiko menarik diri dari lingkungan sosial. Halusinasi, risiko perilaku kekerasan bahkan percobaan bunuh diri merupakan dampak dari harga diri rendah (Anggit, 2017). Gejala negatif yang dialami pasien harga diri rendah kronis diantaranya afek datar, tidak memiliki kemauan, merasa tidak nyaman, dan menarik diri dari masyarakat. Gejala negatif pada pasien harga diri rendah kronis juga tampak dari tidak mampu mengekspresikan perasaan, hilangnya spontanitas dan rasa ingin tahu, menurunnya motivasi, serta hilangnya kemampuan melakukan aktivitas sehari-hari (Widianti, 2017).

Penyakit skizofrenia harga diri rendah kronis seringkali kambuh atau berulang sehingga perlu diberikan terapi jangka lama yaitu dengan memberi asuhan keperawatan jiwa untuk mengontrol perilaku hilangnya rasa percaya diri dari pasien harga diri rendah kronis dengan pemberian intervensi keperawatan jiwa pada pasien harga diri rendah berfokus pada membina hubungan saling percaya, memberi kegiatan sesuai dengan kemampuan pasien, meningkatkan kontak dengan orang lain, mendorong pasien mengungkapkan pikiran dan perasaan serta membantu melihat prestasi, kemampuan dan harapan pasien (Pardede, 2021). 
Berdasarkan survey yang dilakukan oleh penulis di ruang mawar. Didapatkan jumlah data pasien rawat inap sebayak 20 pasien skizofrenia dengan masalah keperawatan gangguan persepsi sensori halusinasi dan harga diri rendah kronis. Subjek dalam pemberian asuhan keperawatan jiwa berjumlah satu orang. Ny. F dijadikan sebagai subjek karena dari hasil pengkajian pasien memiliki masalah keperawatan harga diri rendah .

Berdasarkan latar belakang tersebut, penulis tertarik untuk menulis laporan asuhan keperawatan jiwa ini dengan judul "Asuhan Keperawatan Jiwa pada Ny. F dengan Masalah Harga Diri Rendah Kronis di Ruangan Mawar”.

\subsection{Rumusan Masalah}

Berdasarkan latar belakang masalah tersebut maka dapat dirumuskan masalah sebagai berikut : bagaimana memberikan Asuhan Keperawatan Jiwa pada Ny. F dengan Harga Diri Rendah Kronis di Ruang Mawar.

\subsection{Tujuan Penulisan}

\subsubsection{Tujuan Umum}

Penulis mampu memberikan asuhan keperawatan jiwa pada Ny. F Dengan Harga Diri Rendah Kronis Di Ruang Mawar

\subsubsection{Tujuan Khusus}

1. Mahasiswa mampu melakukan pengkajian pada pasien dengan Harga Diri Rendah Kronis.

2. Mahasiswa mampu menegakkan diagnosa atau masalah keperawatan pada Ny. F dengan Harga Diri Rendah Kronis.

3. Mahasiswa mampu menetapkan intervensi keperawatan secara menyeluruh pada Ny. F dengan Harga Diri Rendah Kronis.

4. Mahasiswa mampu melakukan tindakan keperawatan yang nyata pada Ny. F dengan Harga Diri Rendah Kronis.

5. Mahasiswa mampu mengevaluasi asuhan keperawatan pada $\mathrm{Ny}$. F dengan Harga Diri Rendah Kronis. 
6. Mahasiswa mampu mendokumentasikan asuhan keperawatan pada Ny. F dengan Harga Diri Rendah Kronis. 


\section{BAB 2}

\section{TINJAUAN TEORITIS}

\subsection{Konsep Harga Diri Rendah Kronis}

\subsubsection{Definisi}

Harga diri rendah kronis adalah suatu perasaan dalam diri seseorang yang menganggap bahwa dirinya itu negatif (Irawati, 2019). Harga diri rendah kronik adalah evaluasi diri/perasaan negatif tentang dirinya sendiri atau kemampuan diri yang berlangsung minimal tiga bulan (Keliat, 2020). Harga diri rendah melibatkan evaluasi diri yang negatif dan berhubungan dengan perasaan yang lemah, tidak berdaya, putus asa, ketakutan, rentan, rapuh, tidak lengkap, tidak berharga, dan tidak memadai (Stuart, 2016).

Harga diri rendah kronis merupakan salah satu masalah keperawatan skizofrenia, karena harga diri rendah merupakan gejala negative dari skizofrenia (Pardede, 2020). Harga diri rendah adalah perasaan negatif terhadap dirinya sendiri menyebabkan kehilangan rasa percaya diri, pesimis, dan tidak berharga di kehidupan (Atmojo, 2021). Harga diri rendah merupakan keadaan dimana individu mengalami evaluasi diri negatif tentang kemampuan dirinya. Sehingga dapat diambil kesimpulan bahwa harga diri rendah yaitu seseorang yang mengalami gangguan untuk menilai dirinya sendiri dan kemampuan yang dimilikinya, menyebabkan hilangnya rasa kepercayaan diri yang berlangsung dalam waktu yang lama.

\subsubsection{Faktor Penyebab Harga Diri Rendah Kronis}

Faktor yang mempengaruhi harga diri rendah kronis meliputi faktor Predisposisi dan faktor Presipitasi yaitu (Diana, 2020) :

1. Faktor Predisposisi

a. Faktor yang mempengaruhi harga diri rendah meliputi penolakan dari orang tua, seperti tidak dikasih pujian, dan sikap orang tua yang terlalu mengekang, sehingga anak menjadi frustasi dan merasa tidak berguna lagi serta merasa rendah diri. 
b. Faktor yang mempengaruhi harga diri rendah juga meliputi ideal diri seperti dituntut untuk selalu berhasil dantidak boleh berbuat salah, sehingga anak kehilangan rasa percaya diri.

\section{Faktor Presipitasi}

Faktor presipitasi ditimbulkan dari sumber internal dan eksternal misalnya ada salah satu anggota yang mengalami gangguan mental sehingga keluarga merasa malu dan rendah diri. Pengalaman traumatik juga dapat menimbulkan harga diri rendah seperti penganiayaan seksual, kecelakaan yang menyebabkan seseorang dirawat di rumah sakit dengan pemasangan alat bantu yang tidak nyaman baginya. Respon terhadap trauma umumnya akan mengubah arti trauma dan kopingnya menjadi represi dan denial.

\subsubsection{Tanda dan Gejala Harga Diri Rendah Kronis}

Manifestasi yang biasanya muncul pada pasien dengan masalah harga diri rendah kronis, menurut Keliat (2020) :

1. Mayor

a. Subjektif

1) Menilai diri dengan negatif/mengkritik diri

2) Merasa tidak berarti/tidak berharga

3) Merasa malu/minder

4) Merasa tidak mampu melakukan apapun

5) Meremehkan kemampuan yang dimiliki

6) Merasa tidak memiliki kelebihan

b. Objektif

1) Berjalan menunduk

2) Postur tubuh menunduk

3) Kontak mata kurang

4) Lesu dan tidak bergairah

5) Berbicara pelan dan lirih

6) Ekspresi muka datar 
7) Pasif

2. Minor

a. Subjektif

1) Merasa sulit konsentrasi

2) Mengatakan sulit tidur

3) Mengungkapkan keputusasaan

4) Enggan mencoba hal baru

5) Menolak penilaian positif tentang diri sendiri

6) Melebih-lebihkan penilaian negatif tentang diri sendiri

b. Objektif

1) Bergantung pada pendapat orang lain

2) Sulit membuat keputusan

3) Sering kali mencari penegasan

4) Menghindari orang lain

5) Lebih senang menyendiri

\subsubsection{Proses Terjadinya Harga Rendah Diri}

Harga Diri Rendah terjadi akibat harga diri rendah situasional yang tidak terselesaikan atau ketidakadaan feed back (umpan balik) yang positif dari lingkungan terhadap perilaku pasien sebelumnya. Respon negatif dari lingkungan juga memiliki peran terhadap gangguan harga diri rendah kronis. Pada awalnya pasien dihadapkan dengan stresor (krisis) dan berusaha untuk menyelesaikannya tetapi tidak tuntas. Ketidaktuntasan itu menimbulkan evaluasi diri bahwa ia tidak mampu atau gagal menjalankan peran dan fungsinya. Evaluasi diri yang negatif karena merasa gagal merupakan gangguan harga diri rendah situasional yang berlanjut menjadi harga diri rendah kronis akibat tidak adanya respon positif dari lingkungan pada pasien (Safitri, 2020). Harga diri yang rendah yang dialami seseorang selama lebih dari 3 bulan merupakan harga diri rendah situasional. Sedangkan jika harga diri rendah yang dialami seseorang lebih dari 6 bulan merupakan harga diri rendah kronik yang harus segera ditindak lanjuti (Anggit, 2017). 


\subsubsection{Rentang Respon Harga Diri Rendah Kronis}

Adapun rentang respon harga diri rendah kronis menurut (Dwi, 2020)

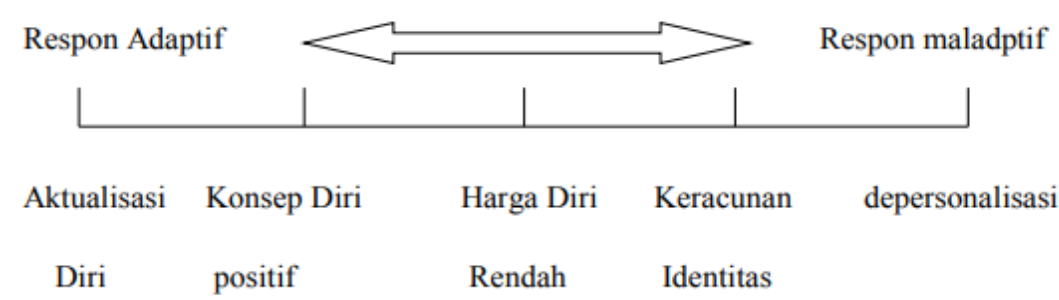

Keterangan :

1. Aktualisasi diri : Pernyataan konsep diri positif dengan pengalaman sukses.

2. Konsep diri positif : Mempunyai pengalaman positif dalam perwujudan dirinya.

3. Harga diri rendah : Perasaan yang negatif pada diri sendiri, hilangnya percaya diri, tidak berharga lagi, tidak berdaya, dan pesimis.

4. Keracunan identitas : Kegagalan seseorang untuk mengintegrasikan berbagai identifikasi masa anak-anak.

5. Dipersonalisasi : Perasaan sulit membedakan diri sendiri dan merasa tidak nyata dan asing

\subsubsection{Mekanisme Koping Harga Diri Rendah Kronis}

Seseorang dengan harga diri rendah kronis memiliki mekanisme koping jangka pendek dan jangka panjang. Jika mekanisme koping jangka pendek tidak memberikan hasil yang telah diharapkan individu, maka individu dapat mengembangkan mekanis koping jangka panjang (Dwi, 2020).

Mekanisme tersebut mencakup sebagai berikut :

1. Jangka Pendek 
a. Aktivitas yang dilakukan untuk pelarian sementara yaitu : pemakaian obat-obatan, kerja keras, nonton tv secara terus menerus.

b. Aktivitas yang memberikan penggantian identitas bersifat sementara, misalnya ikut kelompok sosial, agama, dan politik).

c. Aktivitas yang memberikan dukungan bersifat sementara misalnya perlombaan.

2. Jangka Panjang

Penutupan identitas :

a. terlalu terburu-buru mengadopsi identitas yang disukai dari orang-orang yang berarti tanpa memperhatikan keinginan atau potensi diri sendiri.

b. Identitas Negatif : asumsi identitas yang bertentangan dengan nilai-nilai dan harapan masyarakat.

\subsection{Konsep Asuhan Keperawatan Jiwa}

\subsubsection{Pengkajian Keperawatan}

Pengkajian merupakan pengambilan data yang dilakukan pertama kali oleh perawat setelah pasien masuk. Pengkajian merupakan tahap awal dari proses keperawatan. Disini semua data dikumpulkan secara sistematis untuk menentukan status kesehatan pasien saat ini. Pengkajian harus dilakukan secara komprehensif terkait dengan aspek biologis, psikologis, social maupun spiritual pasien. Pengkajian keperawatan tidak sama dengan pengkajian medis. Pengkajian medis difokuskan pada keadaan patologis, sedangkan pengkajian keperawatan ditujukan pada respon pasien terhadap masalah-masalah kesehatan yang berhubungan dengan pemenuhan kebutuhan dasar manusia. Misalnya dapatkah pasien melakukan aktivitas sehari-hari, sehingga fokus pengkajian pasien adalah respon pasien yang nyata maupun potensial terhadap masalahmasalah aktifitas harian (Sitorus, 2019). 
Menurut Dwi (2020) pengkajian keperawatan jiwa yaitu:

1. Identitas

Nama, umur, jenis kelamin, No MR, tanggal masuk RS, tangal pengkajian.

2. Alasan masuk

Tanyakan kepada pasien dan keluarga apa alasan pasien dibawa ke rumah sakit, Keluhan utama pasien dengan harga diri rendah kronis biasanya merenung atau menyendiri serta mengkritik atau menyalahkan diri sendiri.

3. Faktor Predisposisi

a. Riwayat Kesehatan Dahulu

1) Adanya riwayat gangguan pada pasien atau keluarga.

2) Adanya gangguan fisik atau penyakit termasuk gangguan pertumbuhan dan perkembangan.

b. Riwayat Psikososial

1) Pada pasien harga diri rendah riwayat psikososial yang perlu diketahui adalah pernah atau tidak melakukan atau mengalami dan atau menyaksikan penganiayaan fisik, seksual, penolakan dari lingkungan, kekerasan dalam rumah tangga, aniaya, dan tindakan kriminal.

2) Merasakan pengalaman masa lalu lain yang tidak menyenangkan baik bio, psiko, sosio, kultural, maupun spiritual.

c. Riwayat Penyakit Keluarga Harga diri rendah kronis dapat disebabkan oleh keturunan. Oleh karena itu, pada riwayat penyakit keluarga harus dikaji apakah ada keluarga yang pernah mengalami gangguan jiwa.

4. Faktor presipitasi

Masalah khusus tentang harga diri rendah kronis disebabkan oleh setiap situasi yang dihadapi individu dan ia tak mampu menyelesaikan masalah yang di hadapi . Situasi atas stressor ini dapat mempengaruhi terjadinya harga diri rendah kronis. 
5. Pemeriksaan fisik

Memeriksa tanda-tanda vital, tinggi badan, berat badan, dan tanyakan apakah ada keluhan fisik yang dirasakan pasien.

6. Psikososial

a. Genogram

Perbuatan genogram minumal 3 generasi yang menggambarkan hubungan pasien dengan keluarga, masalah yang terkait dengan komunikasi, pengambilan keputusan, pola asuh, pertumbuhan individu dan keluarga.

b. Konsep Diri

1) Gambaran Diri

Tanyakan persepsi pasien terhadap tubuhnya,bagian tubuh yang disukai,reaksi pasien terhadap bagian tubuh yang tidak disukai dan bagian yang disukai.

2) Identitas Diri

Kaji kepuasan pasien terhadap jenis kelaminya, status sebelum dirawat di rumah sakit. Pasien merasa tidak berdaya dan rendah diri sehingga tidak mempunyai status yang di banggakan atau di harapkan di keluarga ataupun masyarakat.

3) Fungsi peran

Biasanya pasien mengalami penurunan produktifitas dan merasa tidak mampu dalam melaksanakan tugas.

4) Ideal diri

Tanyakan harapan tubuh, posisi status, peran. Harapan pasien terhadap lingkungan, dan harapan pasien terhadap penyakitnya.

5) Harga Diri

Pasien mengejek dan mengkritik dirinya sendiri, menurunkan martabat, menolak kemampuan yang dimiliki. 


\section{c. Hubungan Sosial}

Tanyakan siapa orang terdekat dikehidupan pasien tempat mengadu, berbicara, minta bantuin, atau dukungan. Serta tanyakan organisasi yang diikuti dalam kelompok/ masyarakat.

1) Pasien tidak mempunyai orang yang di anggap sebagai tempat mengadu dan meminta dukungan.

2) Pasien merasa berada di lingkungan yang mengancam.

3) Keluarga kurang memberikan penghargaan kepada pasien.

4) Pasien sulit berinteraksi.

d. Spritual

Nilai dan keyakinan, kegiatan ibadah/ menjalankan keyakinan, kepuasaan dalam menjalankan keyakinan.

1) Falsafah hidup Pasien merasa perjalanan hidupnya penuh dengan ancaman, tujuan hidupnya biasanya jelas.

2) Konsep kebutuan dan praktek keagamaan Pasien mengakui adanya Tuhan tapi tidak yakin terhadap Tuhan, putus asa karena tuhan tidak memberikan sesuai apa yang dia inginkan dan tidak mau menjalankan kegiatan agama.

7. Status Mental

a. Penampilan

Penampilan tidak rapi karena pasien kurang minat untuk perawatan diri. Kemunduran dalam tingkat kebersihan dan kerapian, bau badan karena tidak mandi merupakan salah satu tanda gangguan jiwa dengan harga diri rendah kronis.

b. Pembicaraan

Pasien dengan frekuensi lambat, tertatah, volume suara rendah, sedikit berbicara inkoheren dan bloking. 
c. Aktivitas Motorik

Tegang, lambat, gelisah, dan terjadi penurunan aktivitas interaksi

d. Alam Perasan

Pasien biasanya merasakan tidak mampu dan pandangan hidupnya selalu pesimis.

e. Afek emosi

Terkadang afek pasien tampak tumpul, emosi pasien berubah-ubah, kesepian, apatis, depresi atau sedih, dan cemas.

f. Interaksi selama wawancara

1) Tidak kooperatif, atau mudah tersinggung.

2) Kontak mata kurang: tidak mau menatap lawan bicara.

3) Defensif: selalu mempertahankan pendapat dan kebenaran dirinya.

g. Persepsi-sensori

Pasien mengalami halusinasi dengar/lihat yang mengancam atau memberi perintah.

h. Proses berpikir

1) Arus Pikir:

a) Koheren: pembicaraan dapat dipahami dengan baik.

b) Inkoheren: kalimat tidak berbentuk, kata-kata sulit dipahami.

c) Tangensial: pembicaraan yang berbelit-belit tapi tidak sampai pada tujuan.

d) Flight of ideas: pembicaraan yang melompat dari satu topik ke topik lainnya masih ada hubungan yan tidak logis dan tidak sampai pada tujuan.

e) Bloking: pembicaraan terhenti tiba-tiba kemudian dilanjutkan kembali. 
f) Neologisme: membentuk kata-kata baru yang tidak di pahami oleh umum.

g) Sosiasi bunyi: mengucapkan kata-kata yang mempunyai persamaan bunyi.

2) Isi Pikir: Merasa bersalah dan khawatir, menghukum atau menolak diri sendiri, mengejek dan mengkritik diri sendiri.

i. Tingkat kesadaran

Biasanya pasien tampak bingung dan kacau, stupor adalah gangguan motorik seperti kelakuan, gerakan berulangulang, anggota tubuh pasien dalam sikap canggung yang dipertahankan dalam waktu lama tetapi pasein menyadari semua yang terjadi dilingkungan, sedasi yaitu pasien mengatakan bahwa ia merasa melayang-layang antara sadar atau tidak sadar.

j. Memori

1) Daya ingat jangka panjang:mengingat kejadian masa lalu lebih dari satu bulan

2) Daya ingat jangka menengah:dapat mengingat kejadian yang terjadi 1 minggu terakhir.

3) Daya ingat jangka pendek:dapat mengingat kejadian yang terjadi saat ini.

k. Tingkat konsentrasi dan berhitung

1) Peratikan pasien mudah berganti dari satu obyek ke obyek lain atau tidak.

2) Tidak mampu berkonsentrasi.

3) Tidak mampu berhitung.

1. Kemampuan penilaian mengambil keputusan

1) Ringan: dapat mengambil suatu keputusan yang sederhana dengan dibantu.

2) Bermakna : tidak mampu mengambil suatu keputusan walaupun sudah dibantu. 
m. Daya tilik diri

Pasien tidak menyadari bahwa dia mengalami gangguan jiwa.

\subsubsection{Diagnosa Keperawatan}

Menurut Kuntari (2019) diagnosa yang berkaitan dengan harga diri rendah yaitu:

1. koping individu nefektif

2. isolasi sosial.

3. halusinasi

4. risiko perilaku kekerasan

5. defisit perawatan diri.

\subsubsection{Tindakan Keperawatan}

Pada situasi nyata sering pelaksanaan jauh berbeda dengan rencana, hal ini terjadi karena perawat belum terbiasa menggunakan rencana tertulis dalam melaksanakan tindakan keperawatan. Sebelum melaksanakan tindakan keperawatan yang sudah direncanakan, perawat perlu memvalidasi dengan singkat apakah rencana tindakan masih sesuai dan dibutuhkan pasien sesuai dengan kondisinya (here and now). Perawat juga menilai diri sendiri, apakah kemampuan interpersonal, intelektual, tekhnikal sesuai dengan tindakan yang akan dilaksanakan, dinilai kembali apakah aman bagi pasien. Setelah semuanya tidak ada hambatan maka tindakan keperawatan boleh dilaksanakan (Rokhimma, 2020).

\subsubsection{Evaluasi Keperawatan}

Evaluasi adalah proses yang berkelanjutan untuk menilai efek dari tindakan keperawatan pada pasien. Evaluasi dilakukan terus menerus pada respon pasien terhadap tindakan yang telah dilaksanakan, evaluasi dapat dibagi dua jenis yaitu: evaluasi proses atau formatif dilakukan selesai melaksanakan tindakan. Evaluasi hasil atau sumatif dilakukan 
dengan membandingkan respon pasien pada tujuan umum dan tujuan khusus yang telah ditentukan. Evaluasi keperawatan yang diharapkan pada pasien yang mendapatkan asuhan keperawatan halusinasi, pasien mampu mengenali halusinasi, pasien terlatih mengontrol halusinasi, pasien mampu bercakap-cakap dengan orang lain, pasien mampu beraktivitas secara terjadwal (Andri, 2019). 


\section{BAB 3}

\section{TINJAUAN KASUS}

\subsection{Identitas Pasien}

$\begin{array}{lll}\text { Inisial } & : & \text { Ny.F } \\ \text { Jenis kelamin } & : & \text { Perempuan } \\ \text { Umur } & : & 27 \text { Tahun } \\ \text { Agama } & : & \text { Islam } \\ \text { Status } & : & \text { Lajang } \\ \text { Tanggal pengkajian } & : & \text { 31 Januari } 2022 \\ \text { Informan } & : & \text { Pasien dan buku status }\end{array}$

\subsection{Alasan Masuk Rumah Sakit Jiwa}

Pasien masuk ke rumah sakit jiwa diantar oleh abang kandungnya dan abangnya mengatakan pasien sering merasa dirinya tidak berguna lagi, pasien mengatakan tidak mempunyai kemampuan lagi yang bisa dirinya lakukan, Berdasarkan informasi yang diperoleh dari buku status, pasien ketika pertama kali masuk RSJ sempat tidak mau makan dan minum hanya termenung saja, dan ketika pasien disuruh mandi pasien hanya diam dan menangis saja.

\subsection{Faktor Predisposisi}

Pasien tidak pernah mengalami kejang. Tidak ada keluarga yang punya penyakit gangguan jiwa. Sebelumnya pasien pernah mengalami gangguan jiwa dan di rawat di RSJ Prof. Dr. M. Ildrem pada tahun 2021, yang mengakibatkan pasien menjadi gangguan jiwa ketika ayahnya meninggal dunia dan pasien mengatakan pernah bersetubuh dengan kakek tirinya. Ny.F menarik diri, merasa dirinya tidak berguna lagi sehingga ia lebih menutup diri. Masalah keperawatan yang muncul : Harga Diri Rendah Kronis 


\subsection{Fisik}

Pasien tidak memiliki keluhan fisik, saat dilakukan pemeriksaan tanda-tanda vital, didapatkan hasil TD : 120/80 mmHg ; $\mathrm{N}: 75 x / \mathrm{i} ; \mathrm{S}: 37^{\circ} \mathrm{C} ; \mathrm{P}: 20 \mathrm{x} / \mathrm{i}$. Pasien memiliki tinggi badan $155 \mathrm{~cm}$ dan berat badan $60 \mathrm{Kg}$.

\subsection{Psikososial}

\subsubsection{Genogram}

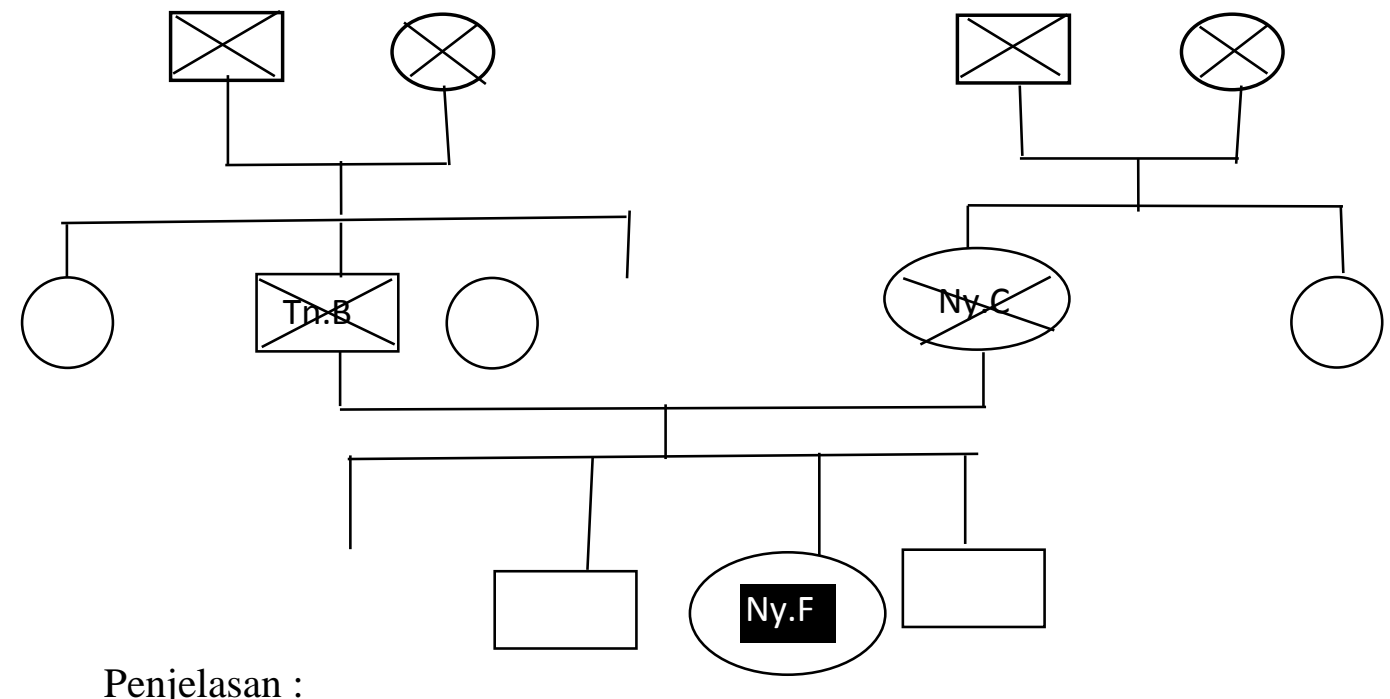

Pasien anak ketiga dari 4 bersaudara, pasien berinisial Ny.F ,anak yatim piatu orangtuanya meninggal sekitar 15 tahun yg lalu.

Keterangan :

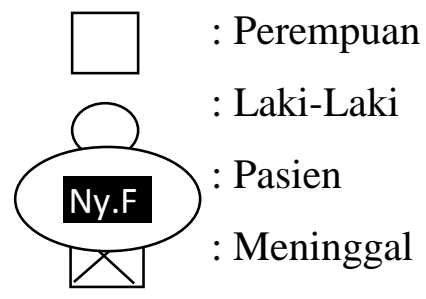

\subsubsection{Konsep Diri}

1. Gambaran diri : Pasien menyukai seluruh tubuhnya dan tidak ada yang cacat

2. Identitas : Pasien anak ke 2 dari 4 bersaudara, Pasien lulusan SMA yang saat ini tidak memiliki pekerjaan 
3. Peran : Pasien tidak menjalankan peran dalam keluarga

4. Ideal diri : Pasien ingin cepat sembuh

5. Harga diri

- Pasien mengatakan merasa tidak dihargai dan pasien merasa tidak berguna

- Pasien mengatakan merasa minder dan malu karena tidak bisa melakukan apapun dalam hidupnya.

- Merasa malu karena masuk rumah sakit jiwa

- Merasa tidak mampu menjadi ibu yang baik karena takut anaknya diejek anak orang gila

Masalah Keperawatan : Harga diri rendah kronis

\subsubsection{Hubungan Sosial}

1. Peran serta dalam kegiatan kelompok/masyarakat : Pasien bersifat apatis. Pasien jarang mengikuti kegiatan kelompok di rumah sakit jiwa seperti beribadah, bergotong royong (memberikan halaman rumah, membakar sampah). Pasein mengatakan lebih suka sendiri, pasien mengatakan berbeda dengan orang lain

2. Hambatan dalam berbuhungan dengan orang Lain : Penyakitnya yaitu gangguan jiwa. Pasien hanya berbicara seperlunya saja. Ketika di tanya, pasien hanya sebatas menjawab pertanyaan kita, lalu kebanyakan diam

Masalah Keperawatan: Isolasi Sosial

\subsubsection{Spiritual}

1. Nilai dan Keyakinan : Pasien beragama Islam

2. Kegiatan Ibadah : Pasien sering melakukan kegiatan keagamaan di rumah sakit dengan motivasi.

\subsection{Status Mental}


1. Penampilan

Pasien berpenampilan tidak rapi

2. Pembicaraan

Pasien mampu menjawab pertanyaan dengan jelas tetapi tidak dapat cepat memahami pertanyaan yang diberikan.

3. Aktivitas Motorik

Pasien tampak lambat berjalan namun dapat melakukan kegiatan yang lain seperti makan dan mandi.

4. Suasana perasaan

Pasien merasa tidak dianggap ada lagi oleh keluarganya karena tidak pernah di jenguk selama di rawat di rumah sakit jiwa. Dan merasa minder dengan orang lain karena tidak dapat melakukan kegiatan apapun lagi.

Masalah keperawatan : Harga Diri Rendah Kronis

5. Afek

Pasien berespon dengan baik

6. Interaksi selama wawancara

Pasien kooperatif, tidak ada kontak mata pada lawan bicara, sering menunduk dan tidak banyak bicara.

7. Persepsi

Pasien mengatakan sering mendengar suara - suara yang memanggil namanya namun orangnya tidak terlihat, suara yang di dengar mirip sura ibunya, terdengar $3 \mathrm{x}$ sehari, saat pagi, siang dan sore, saat dirinya sendiri dan melamun suara itu muncul, dirinya menjadi sedih dan hanya mampu menutup telinga saja saat suara itu muncul.

8. Proses Pikir

Pasien mampu menjawab apa yang ditanya dengan baik.

9. Isi pikir

Pasien mengatakan dirinya selalu berpikir dirinya tidak berguna

10. Tingkat kesadaran

Tingkat kesadaran pasien composmentis dan mampu melakukan orientasi orang, waktu dan tempat.

11. Memori 
Pasien mampu menceritakan kejadian di masa sekitar 5 tahun yang lalu bahwa diri diperkosa oleh kakek tirinya.

12. Tingkat konsentrasi berhitung

Pasien mampu berkonsentrasi dalam perhitungan sederhana tanpa bantuan orang lain yaitu pasien mampu menjawab soal $30 \times 2=60$

13. Kemampuan penilaian

Pasien dapat membedakan hal yang baik dan yang buruk.

14. Daya tilik diri

Pasien tidak mengingkari penyakit yang diderita, pasien mengetahui bahwa dia memiliki harga diri rendah, karena selalu merasa dirinya tidak ada gunanya lagi hidup di dunia ini.

\subsection{Mekanisme Koping}

Pasien mengalami mekanisme koping adaptif yaitu pasien dapat berbicara baik dengan orang lain.

\subsection{Masalah Psikososial dan Lingkungan}

Pasien mengatakan sulit berteman dengan orang lain karena pasien lebih banyak diam, pasien sangat sulit untuk memulai pembicaraan dengan orang lain. Lebih sering termenung sendirian.

\subsection{Pengetahuan Kurang Tentang Gangguan Jiwa}

Pasien tidak mengetahui tentang penyakit gangguan jiwa dan pasien tahu obat apa yang diminum nya setiap hari yang diberikan oleh staf pegawai rumah sakit jiwa.

\subsection{Aspek Medik}

Resperidone 2mg 2x1

Clozapine 25mg 1x1

\subsection{Analisa Data}

\section{No.}




\begin{tabular}{|c|c|c|}
\hline 1. & $\begin{array}{ll}\text { DS : } & \\
\text { - } & \text { Pasien mengatakan merasa tidak } \\
& \text { dihargai dan pasien merasa tidak } \\
& \text { berguna } \\
\text { - } & \text { Pasien mengatakan merasa minder } \\
& \text { dan malu karena tidak bisa } \\
& \text { melakukan apapun dalam } \\
& \text { hidupnya. } \\
\text { - } & \text { Merasa malu karena masuk rumah } \\
& \text { sakit jiwa } \\
\text { - } & \text { Merasa tidak mampu menjadi ibu } \\
& \text { yang baik karena takut anaknya } \\
& \text { diejek anak orang gila } \\
\text { DO : } & \\
\text { - } & \text { Pasien tampak menilai diri } \\
& \text { negative/ mengkritik diri } \\
\text { - } & \text { Pasien tampak berjalan menunduk } \\
- & \text { Postur tubuh pasien tampak } \\
& \text { menunduk } \\
\text { - } & \text { Kontak mata pasien kurang } \\
\text { - } & \text { Pasien tampak lesu dan tidak } \\
& \text { bergairah } \\
\text { - } & \text { Pasien bergantung pada pendapat } \\
\text { - } & \text { Orang lain } \\
\text { - } & \text { Pasien sering mencari penegasan berbicara pelan dan lirih } \\
\end{array}$ & $\begin{array}{l}\text { Gangguan Konsep Diri : } \\
\text { Harga diri rendah kronis }\end{array}$ \\
\hline 2. & $\begin{aligned} \text { DS : } & \\
\text { - } & \text { Pasein mengatakan ingin sendiri } \\
\text { - } & \text { Pasien mengatakan berbeda dengan } \\
& \text { orang lain } \\
\text { DO : } & \\
\text { - } & \text { Pasien tampak menarik diri } \\
- & \text { Pasien tampak menolak } \\
& \text { melakukan interaksi } \\
\text { - } & \text { Pasien tampak tidak ada kontak } \\
& \text { mata } \\
\text { - } & \text { Pasien tampak lesu } \\
- & \text { Pasien tampak tidak bergairah }\end{aligned}$ & Isolasi Sosial \\
\hline 3. & $\begin{array}{ll}\text { DS : } & \\
\text { - } & \text { Pasien mengatakan sering } \\
& \text { mendengar suara - suara yang } \\
& \text { memanggil namanya namun } \\
& \text { orangnya tidak terlihat, suara yang } \\
& \text { di dengar mirip sura ibunya, } \\
& \text { terdengar 3x sehari, saat pagi, } \\
& \text { siang dan sore, saat dirinya sendiri }\end{array}$ & $\begin{array}{l}\text { Gangguan Persepsi } \\
\text { Sensori : Halusinasi } \\
\text { Pendengaran }\end{array}$ \\
\hline
\end{tabular}




\begin{tabular}{|c|}
\hline $\begin{array}{ll}\text { dan melamun suara itu muncul, } \\
\text { dirinya menjadi sedih dan hanya } \\
\text { mampu menutup telinga saja saat } \\
\text { suara itu muncul. } \\
\text { DO : } \\
\text { - Pasien tampak menutup telinganya } \\
\text { saat suara itu datang memanggil } \\
\text { namanya } \\
\text { - } \text { Pasien tampak berbicara ngawur } \\
\text { dan senyum - senyum sendiri } \\
\text { - Pasien tampak sering menyendiri } \\
\text { - } \text { Pasien tampak mondar-mandir } \\
\text { - Pasien tampak diam sambil } \\
\text { menikmati hasinasinya } \\
\text { - Pasien tampak curiga. }\end{array}$ \\
\hline
\end{tabular}

\subsection{Masalah Keperawatan}

1. Gangguan konsep diri : Harga diri rendah kronis

2. Isolasi sosial

3. Gangguan persepsi sensori : Halusinasi pendengaran

\subsection{Pohon Masalah}

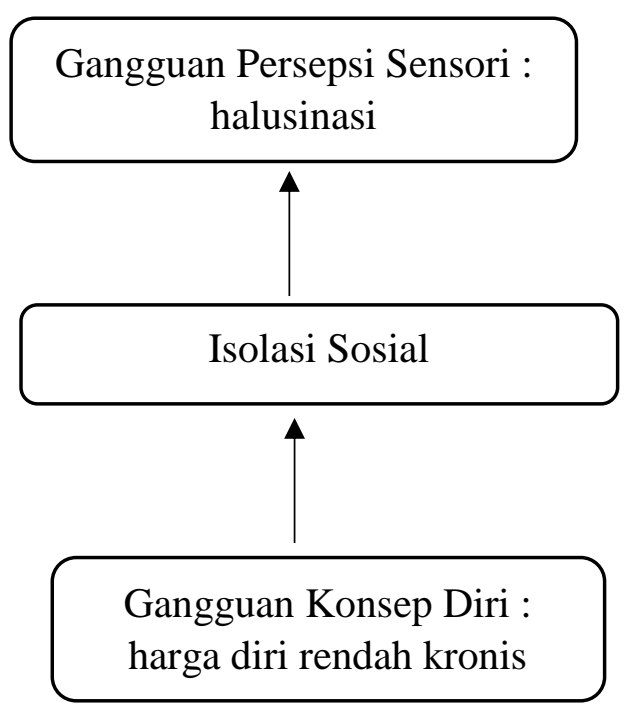

\subsection{Prioritas Diagnosa Keperawatan}

1. Gangguan konsep diri : Harga diri rendah kronis

2. Gangguan Persepsi Sensori : Halusinasi pendengaran 
3. Isolasi Sosial

3.15 Intervensi Keperawatan

\begin{tabular}{|c|c|c|c|}
\hline $\begin{array}{c}\text { Diagnosa } \\
\text { Keperawatan }\end{array}$ & Tujuan & Kriteria Hasil & Intervensi \\
\hline $\begin{array}{l}\text { Gangguan } \\
\text { konsep diri : } \\
\text { harga diri } \\
\text { rendah }\end{array}$ & $\begin{array}{l}\text { Pasien dapat } \\
\text { meningkatkan } \\
\text { harga dirinya }\end{array}$ & $\begin{array}{l}\text { 1. Pasien mampu } \\
\text { mengidentifikasi } \\
\text { kemampuan dan } \\
\text { aspek positif } \\
\text { yang dimiliki } \\
\text { 2. Pasien mampu } \\
\text { menilai } \\
\text { kemampuan yang } \\
\text { dapat digunakan } \\
\text { 3. Pasien mampu } \\
\text { menetapkan/me } \\
\text { milih kegiatan } \\
\text { sesuai } \\
\text { kemampuan } \\
\text { 4. Pasien mampu } \\
\text { melatih kegiatan } \\
\text { sesuai } \\
\text { kemampuan yang } \\
\text { dipilih satu } \\
\text { 5. Pasien mampu } \\
\text { melatih kegiatan } \\
\text { sesuai } \\
\text { kemampuan yang } \\
\text { dipilih dua } \\
\text { Pasien mampu } \\
\text { melatih kegiatan } \\
\text { sesuai } \\
\text { kemampuan yang } \\
\text { dipilih tiga }\end{array}$ & $\begin{array}{l}\text { Sp 1: } \\
\text { Mengidentifikasi } \\
\text { kemampuan dan aspek } \\
\text { positif yang dimiliki } \\
\text { Sp 2: } \\
\text { 1. Menilai kemampuan } \\
\quad \text { yang dapat digunakan } \\
\text { 2. Menetapkan/memilih } \\
\text { kegiatan sesuai } \\
\quad \text { kemampuan kegiatan } \\
\text { 3. Melatih kemampuan } \\
\text { sesuai kesuat } \\
\quad \text { yang dipilih satu } \\
\text { Sp 3: } \\
\text { Melatih kegiatan sesuai } \\
\text { kemampuan yang dipilih } \\
\text { dua } \\
\text { Sp 4: } \\
\text { Melatih kegiatan sesuai } \\
\text { kemampuan yang dipilih } \\
\text { tiga }\end{array}$ \\
\hline $\begin{array}{l}\text { Gangguan } \\
\text { Persepsi } \\
\text { Sensori } \\
\text { Halusinasi }\end{array}$ & $\begin{array}{l}\text { Pasien dapat } \\
\text { mengontrol } \\
\text { halusinasinya }\end{array}$ & $\begin{array}{l}\text { 1. Pasien mampu } \\
\text { mengenal } \\
\text { halusinasinya } \\
\text { 2. Pasien mampu } \\
\text { Mengontrol } \\
\text { halusinasi } \\
\text { dengan cara } \\
\text { menghardik } \\
\text { 3. Pasien mampu } \\
\text { mengontrol } \\
\text { halusinasi } \\
\text { dengan makan } \\
\text { obat teratur }\end{array}$ & 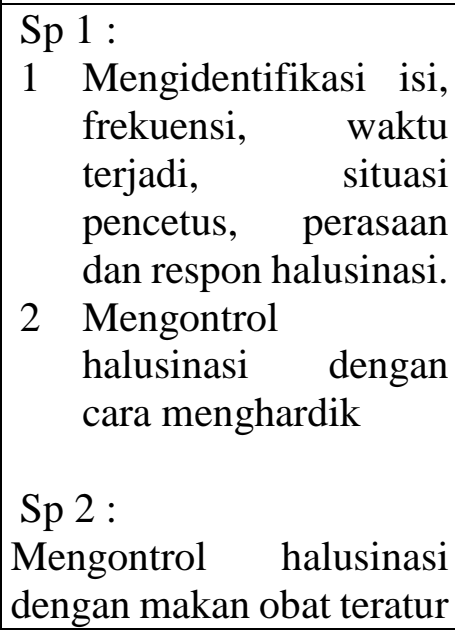 \\
\hline
\end{tabular}




\begin{tabular}{|c|c|c|c|}
\hline & & $\begin{array}{l}\text { 4. Pasien mampu } \\
\text { mengontrol } \\
\text { halusinasi } \\
\text { dengan bercakap- } \\
\text { cakap dengan } \\
\text { orang lain } \\
\text { 5. Pasien mampu } \\
\text { mengontrol } \\
\text { halusinasi } \\
\text { dengan } \\
\text { melakukan } \\
\text { kegiatan } \\
\text { terjadwal. }\end{array}$ & $\begin{array}{l}\text { Sp 3 : } \\
\text { Mengontrol halusinasi } \\
\text { dengan bercakap-cakap } \\
\text { dengan orang lain } \\
\text { Sp } 4 \text { : } \\
\begin{array}{l}\text { Mengontrol halusinasi } \\
\text { dengan melakukan } \\
\text { kegiatan terjadwal. }\end{array}\end{array}$ \\
\hline Isolasi Sosial & $\begin{array}{l}\text { Pasien dapat } \\
\text { berinteraksi } \\
\text { dengan orang } \\
\text { lain }\end{array}$ & 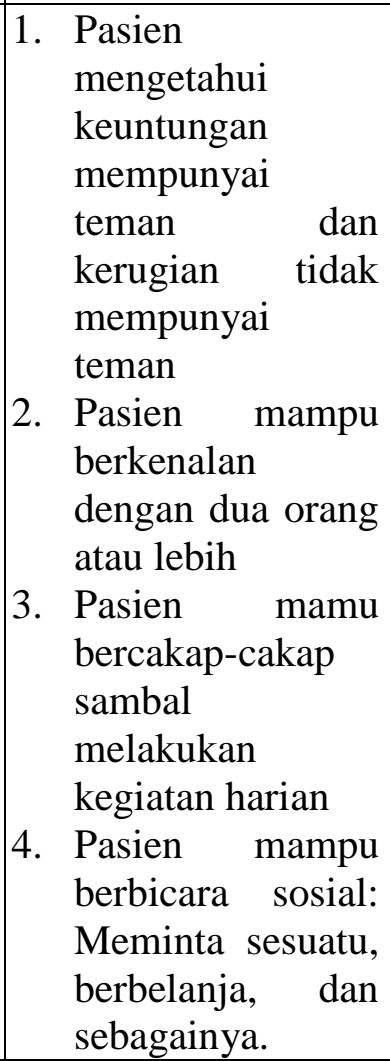 & $\begin{array}{l}\text { Sp 1: } \\
\text { Menjelaskan keuntungan } \\
\text { mempunyai teman dan } \\
\text { kerugian tidak } \\
\text { mempunyai teman. } \\
\text { Sp 2: } \\
\text { Latih pasien berkenalan } \\
\text { dengan dua orang atau } \\
\text { lebih } \\
\text { Sp 3 : } \\
\text { Latih pasien bercakap- } \\
\text { cakap sambal melakukan } \\
\text { kegiatan harian } \\
\text { Sp 4: } \\
\text { Latih pasienn berbicara } \\
\text { social: meminta sesuatu, } \\
\text { berbelanja } \\
\text { sebagainya }\end{array}$ \\
\hline
\end{tabular}


3.16 Implementasi Keperawatan

\begin{tabular}{|c|c|c|}
\hline $\begin{array}{c}\text { Hari / } \\
\text { Tanggal }\end{array}$ & Implementasi & Evaluasi \\
\hline $\begin{array}{l}\text { Rabu, } 02 \\
\text { Februari } \\
2022 . \\
10.30 \\
\text { Wib. }\end{array}$ & 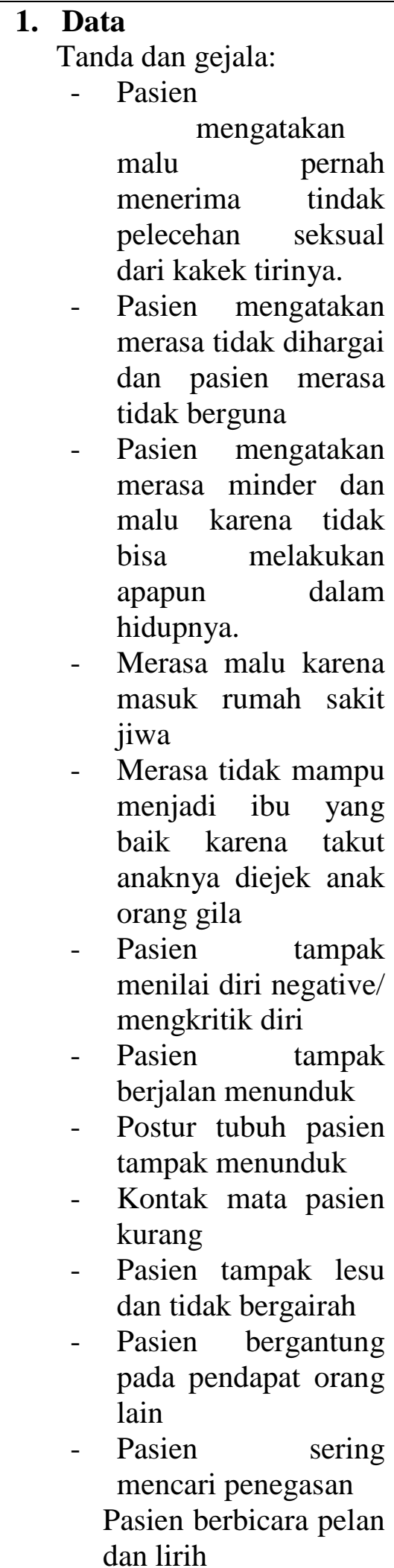 & 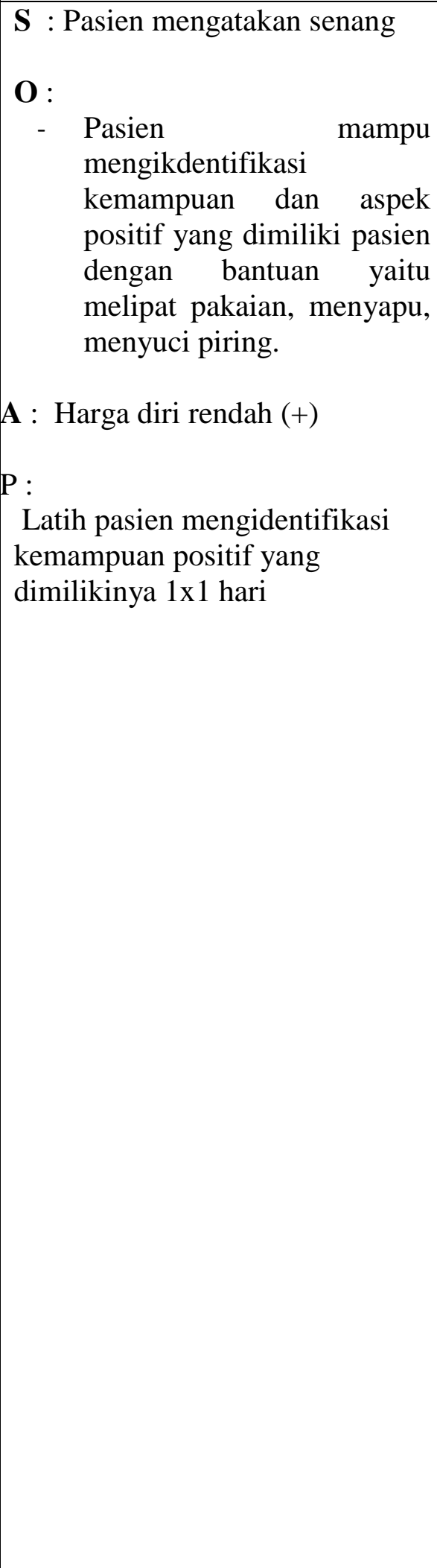 \\
\hline
\end{tabular}




\begin{tabular}{|c|c|c|}
\hline & $\begin{array}{l}\text { Kemampuan: Menyapu } \\
\text { rumah } \\
\text { 2. Diagnosa Keperawatan } \\
\text { Gangguan konsep diri : } \\
\text { Harga Diri Rendah } \\
\text { Kronis } \\
\text { 3. Tindakan Keperawatan } \\
\text { Sp1: } \\
\text { Mengidentifikasi } \\
\text { kemampuan dan aspek } \\
\text { positif yang dimiliki } \\
\text { pasien } \\
\text { RTL } \\
\text { - Sp2: } \\
\text { - Menilai kemampuan } \\
\text { yang dapat digunakan } \\
\text { - Menetapkan/memilih } \\
\text { kegiatan } \\
\text { kemampuan sesuai } \\
\text { - Latih kegiatan sesuai } \\
\text { kemampuan yang } \\
\text { dipilih 1 }\end{array}$ & \\
\hline $\begin{array}{l}\text { Kamis, } 03 \\
\text { Februari } \\
2022 . \\
\quad 10.30 \\
\quad \text { Wib. }\end{array}$ & $\begin{array}{l}\text { 1. Data } \\
\text { Tanda dan gejala: } \\
\text { - } \text { Pasien } \\
\text { malu mengatakan } \\
\text { menerima pernah } \\
\text { pelecehan seksual } \\
\text { dari kakek tirinya. } \\
\text { - } \\
\text { Pasien mengatakan } \\
\text { merasa tidak dihargai } \\
\text { dan pasien merasa } \\
\text { tidak berguna } \\
\text { - Pasien mengatakan } \\
\text { merasa minder dan } \\
\text { malu karena tidak } \\
\text { bisa melakukan } \\
\text { apapun dalam } \\
\text { hidupnya. } \\
\text { Pasien tampak } \\
\text { berjalan menunduk } \\
\text { - Postur tubuh pasien } \\
\text { tampak menunduk }\end{array}$ & 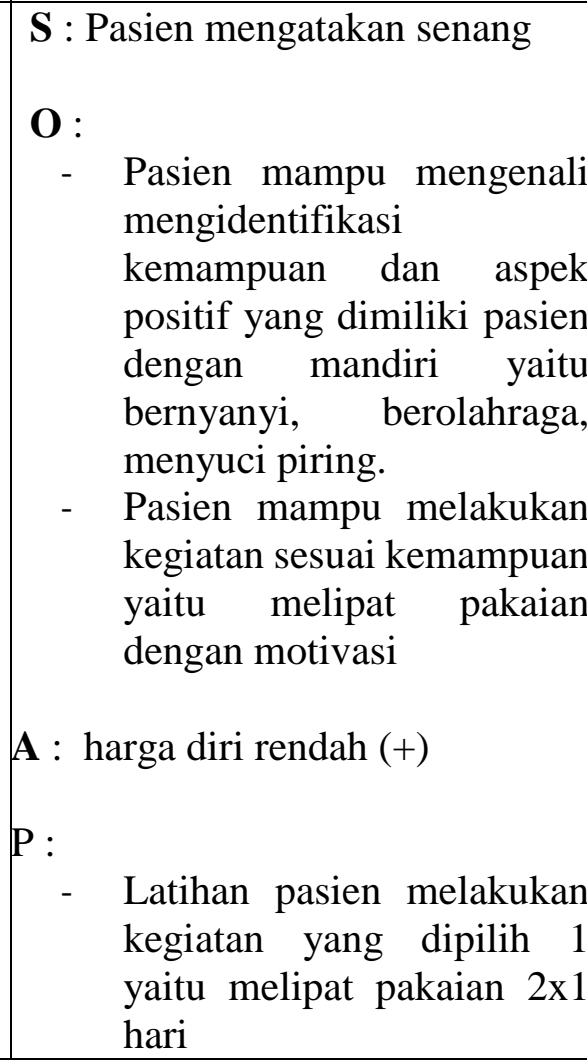 \\
\hline
\end{tabular}




\begin{tabular}{|c|c|c|}
\hline & 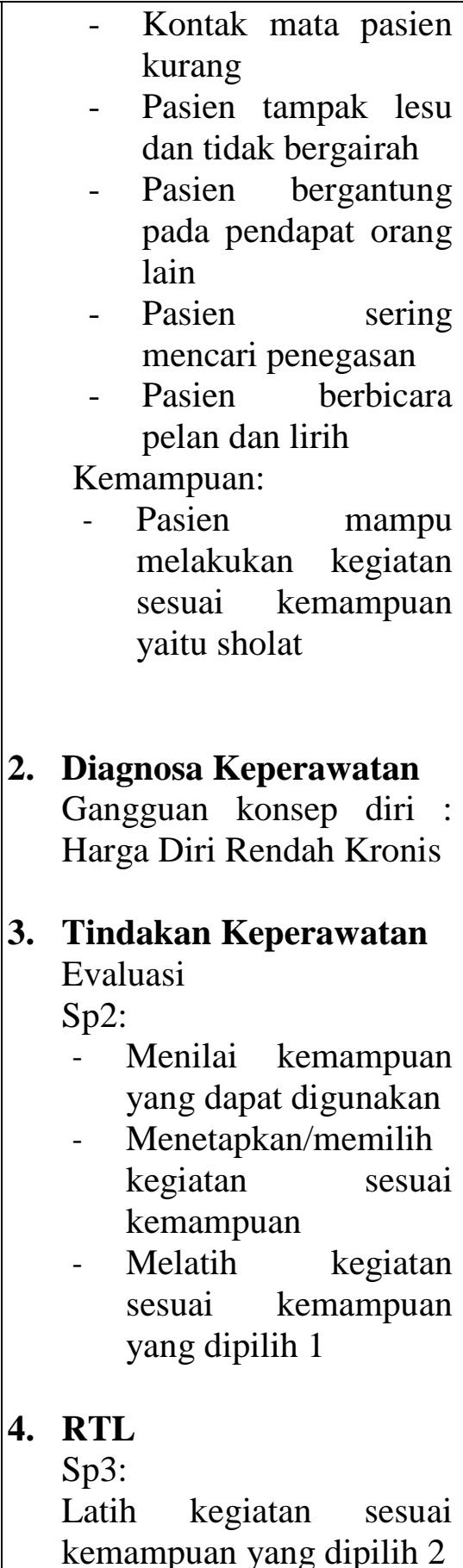 & \\
\hline $\begin{array}{l}\text { Jumat, } 04 \\
\text { Februari } \\
2022 \\
10.30 \mathrm{ib}\end{array}$ & $\begin{array}{l}\text { 1. Data } \\
\text { Tanda dan gejala: } \\
\text { - Pasien mengatakan } \\
\text { malu pernah menerima } \\
\text { tindak pelecehan } \\
\text { seksual dari kakek } \\
\text { tirinya. } \\
\text { - Pasien mengatakan } \\
\text { merasa tidak dihargai } \\
\text { dan pasien merasa tidak }\end{array}$ & $\begin{array}{l}\text { S : Pasien mengatakan senang } \\
\text { O : } \\
\text { - } \\
\text { Pasien mampu melakukan } \\
\text { kegiatan sesuai kemampuan } \\
\text { yaitu sholat dengan } \\
\text { motivasi } \\
- \text { Pasien mampu melakukan } \\
\text { kegiatan sesuai kemampuan } \\
\text { yaitu merapikan tempat } \\
\text { tidur dengan mandiri }\end{array}$ \\
\hline
\end{tabular}




\begin{tabular}{|c|c|c|}
\hline & 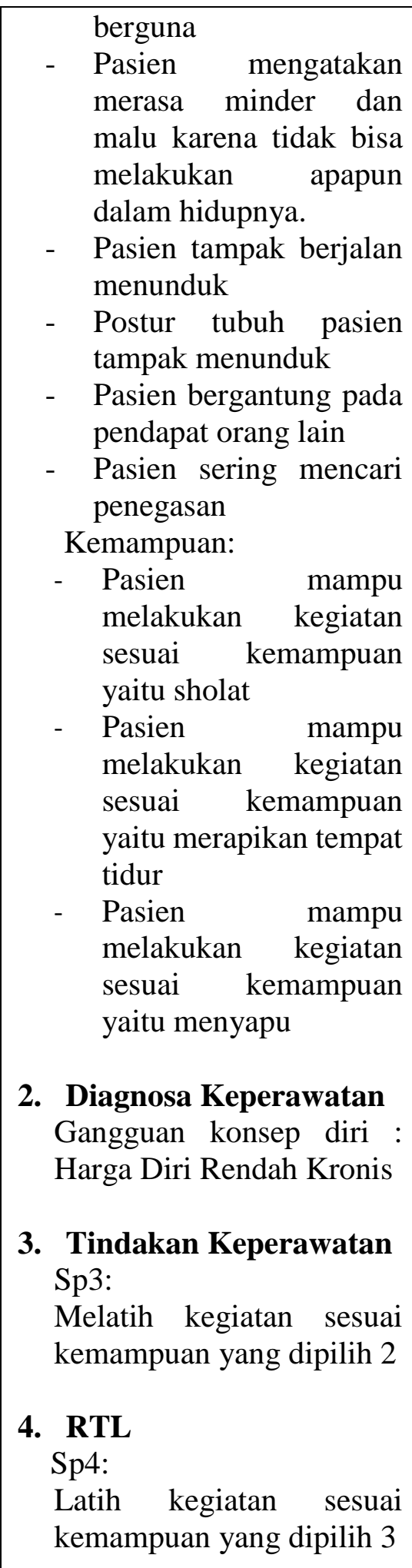 & 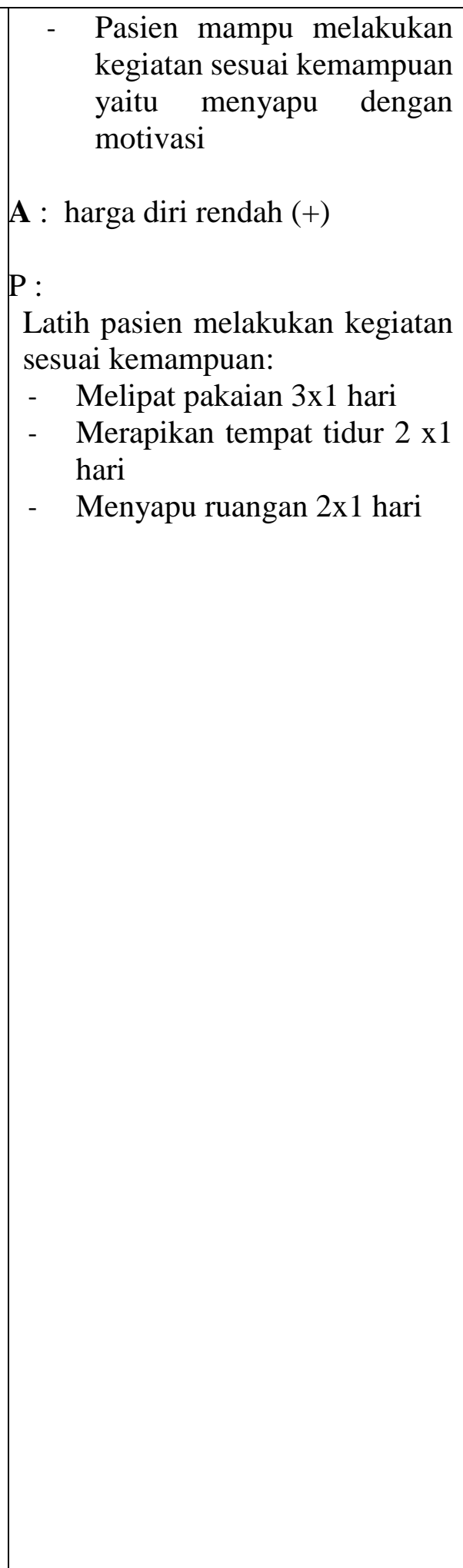 \\
\hline $\begin{array}{l}\text { Sabtu, } 05 \\
\text { Februari } \\
2022 \\
14.00 \text { wib }\end{array}$ & $\begin{array}{l}\text { 1. Data } \\
\text { Tanda dan gejala: } \\
\text { - } \quad \begin{array}{l}\text { Pasien tampak berjalan } \\
\text { menunduk }\end{array} \\
\end{array}$ & $\begin{array}{l}\mathbf{S}: \text { Pasien mengatakan senang } \\
\mathbf{O}:\end{array}$ \\
\hline
\end{tabular}




\begin{tabular}{|c|c|}
\hline 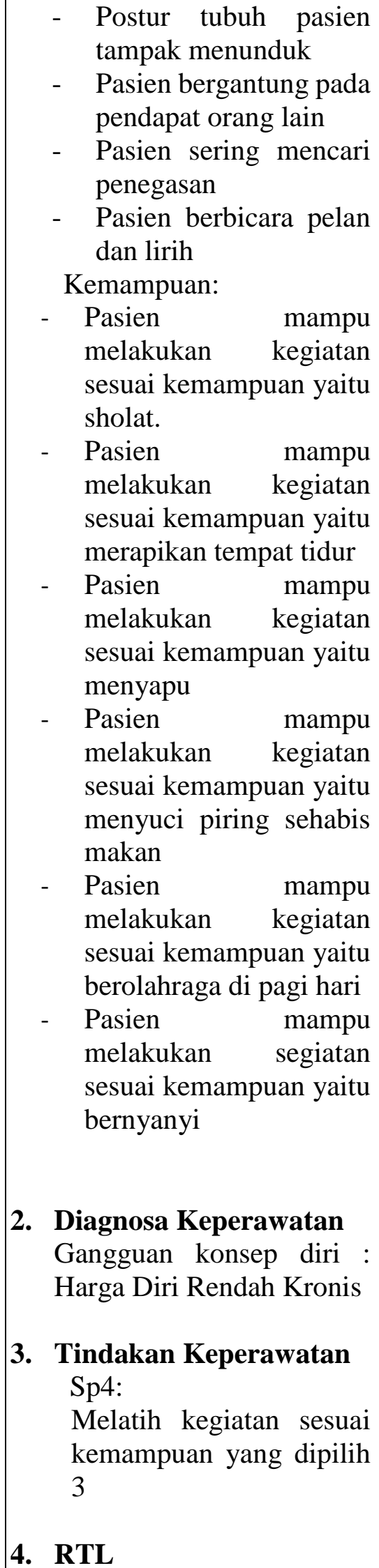 & 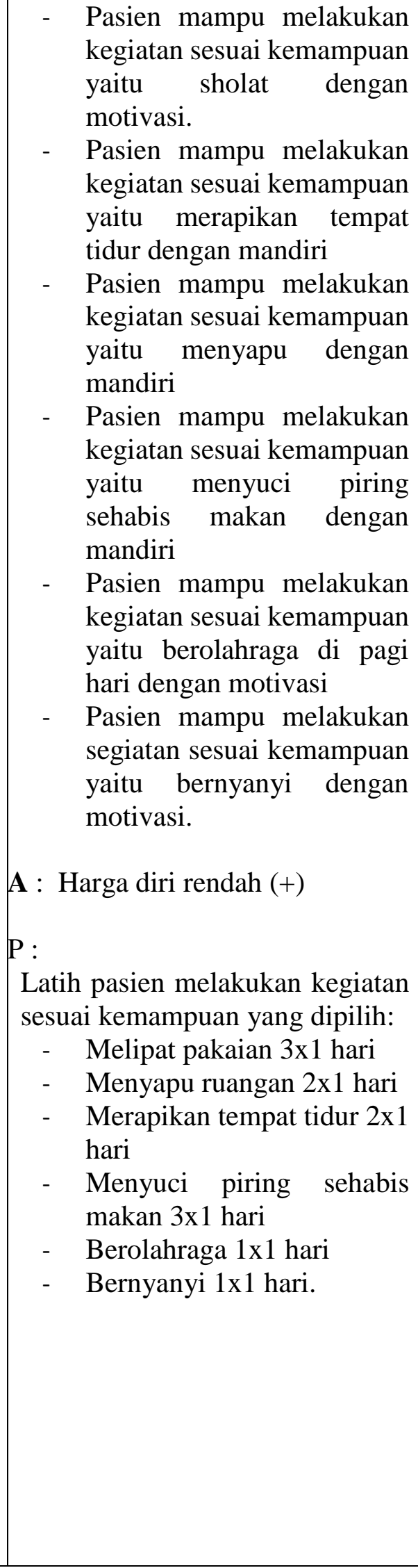 \\
\hline
\end{tabular}




\begin{tabular}{|c|c|c|c|}
\hline & & $\begin{array}{l}\text { Follow up dan evaluasi } \mathrm{Sp} \\
1 \text { - } 4 \text { harga diri rendah }\end{array}$ & \\
\hline $\begin{array}{l}\text { Senin, } 07 \\
\text { Februari } \\
2022 \\
10.30 \\
\text { WIB. }\end{array}$ & & 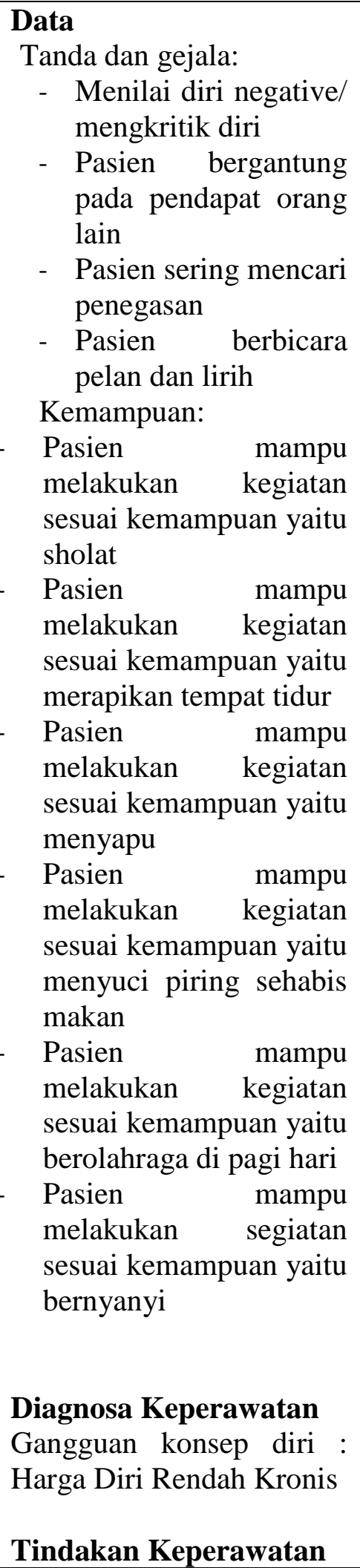 & 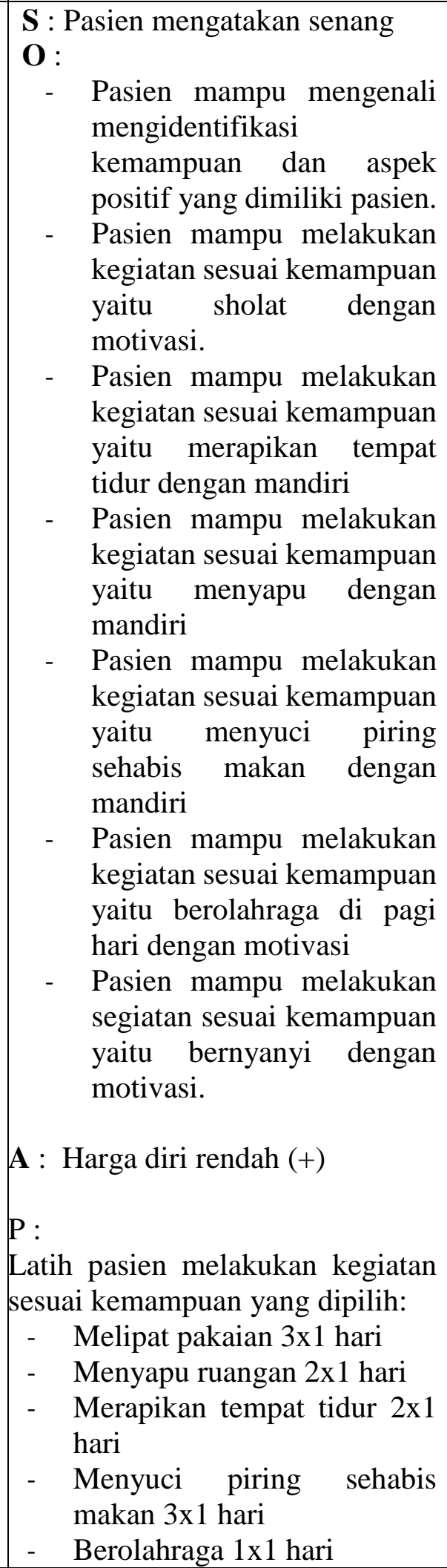 \\
\hline
\end{tabular}




\begin{tabular}{|c|c|c|}
\hline & $\begin{array}{l}\text { Sp1: } \\
\text { Mengidentifikasi } \\
\text { kemampuan dan aspek } \\
\text { positif yang dimiliki pasien } \\
\text { Sp2: } \\
\text { - Menilai kemampuan } \\
\text { yang dapat digunakan } \\
\text { - Menetapkan/ memilih } \\
\text { kegiatan sesuai } \\
\text { kemampuan. } \\
\text { - Melatih kegiatan } \\
\text { sesuai kemampuan } \\
\text { yang dipilih 1 } \\
\text { Sp3: } \\
\text { Melatih kegiatan sesuai } \\
\text { kemampuan yang dipilih } 2 \\
\text { Sp4: } \\
\text { Melatih kegiatan sesuai } \\
\text { kemampuan yang dipilih } 3 \\
\text { RTL } \\
\text { 4p1 Isolasi Sosial: } \\
\text { Menjelaskan Keuntungan } \\
\text { mempunyai teman dan } \\
\text { kerugian tidak mempunyai } \\
\text { teman } \\
\text { Sp2: } \\
\text { Melatih pasien berkenalan } \\
\text { dengan dua orang atau } \\
\text { lebih }\end{array}$ & - $\quad$ Bernyanyi 1x1 hari. \\
\hline $\begin{array}{l}\text { Selasa, } 08 \\
\text { Februari } \\
2022 \\
10.30 \\
\text { WIB. }\end{array}$ & $\begin{array}{l}\text { 1. Data } \\
\text { Tanda dan gejala : } \\
\text { - } \quad \text { Pasein mengatakan } \\
\text { ingin sendiri } \\
\text { - } \text { Pasien mengatakan } \\
\text { berbeda dengan orang } \\
\text { lain } \\
\text { - Pasien tampak menarik } \\
\text { diri } \\
\text { - Pasien tampak } \\
\text { menolak melakukan } \\
\text { interaksi } \\
\text { - Pasien tampak tidak } \\
\text { - } \text { ada kontak mata } \\
\text { Pasien tampak lesu }\end{array}$ & $\begin{array}{ll}\text { S : Pasien mengatakan senang } \\
\text { O: } & \\
\text { - } & \text { Pasien mampu } \\
& \text { menjelaskan keuntungan } \\
& \text { mempunyai teman dan } \\
& \text { kerugian tidak mempunyai } \\
& \text { teman dengan bantuan } \\
\text { - } & \begin{array}{l}\text { Pasien mampu berkenalan } \\
\text { dengan 2 orang dengan }\end{array} \\
& \text { motivasi } \\
\text { A : } & \text { Isolasi sosial (+). } \\
\text { P : } & \end{array}$ \\
\hline
\end{tabular}




\begin{tabular}{|c|c|c|}
\hline & $\begin{array}{l}\text { - } \begin{array}{l}\text { Pasien tampak tidak } \\
\text { bergairah }\end{array} \\
\text { Kemampuan: Menyapu } \\
\text { rumah } \\
\text { 2. Diagnosa Keperawatan } \\
\text { Isolasi Sosial } \\
\text { 3. Tindakan Keperawatan } \\
\text { Sp1: } \\
\text { Menjelaskan Keuntungan } \\
\text { mempunyai teman dan } \\
\text { kerugian tidak mempunyai } \\
\text { teman } \\
\text { Sp2: } \\
\text { Melatih pasien berkenalan } \\
\text { dengan dua orang atau } \\
\text { lebih } \\
\text { RTL } \\
\text { Sp3: } \\
\text { Latih pasien bercakap- } \\
\text { cakap sambil melakukan } \\
\text { kegiatan harian } \\
\text { Latih pasien berbicara } \\
\text { sosial: meminta sesuatu, } \\
\text { berbelanja, dll. }\end{array}$ & $\begin{array}{l}\text { - Latihan berkenalan dengan } \\
\text { satu orang } 1 \times 1 \text { hari }\end{array}$ \\
\hline $\begin{array}{l}\text { Rabu, } 09 \\
\text { Februari } \\
2022 . \\
11.30 \mathrm{Wib}\end{array}$ & $\begin{array}{l}\text { 1. Data } \\
\text { Tanda dan gejala : } \\
\text { - } \text { Pasien mengatakan } \\
\text { berbeda dengan orang } \\
\text { lain } \\
\text { - } \text { Pasien tampak menarik } \\
\text { diri } \\
\text { - } \text { Pasien tampak lesu } \\
\text { - } \text { Pasien tampak tidak } \\
\text { bergairah } \\
\text { Kemampuan: } \\
\text { - Pasien } \\
\text { menjelaskan mampu } \\
\text { keuntungan } \\
\text { mempunyai teman dan } \\
\text { kerugian tidak } \\
\text { mempunyai teman } \\
\text { Pasien mampu } \\
\text { berkenalan dengan } 2 \\
\text { orang }\end{array}$ & $\begin{array}{l}\text { S : Pasien mengatakan senang } \\
\text { O: } \\
\text { - } \text { Pasien mampu } \\
\text { menjelaskan keuntungan } \\
\text { mempunyai teman dan } \\
\text { kerugian tidak mempunyai } \\
\text { teman dengan bantuan } \\
\text { - } \text { Pasien mampu berkenalan } \\
\text { dengan 1 orang dengan } \\
\text { bantuan } \\
\text { Pasien mampu bercakap- } \\
\text { cakap sambil melakukan } \\
\text { kegiatan harian dengan } \\
\text { bantuan } \\
\text { Pasien mampu berbicara } \\
\text { sosial: meminta sesuatu } \\
\text { dengan motivasi } \\
\text { A : Isolasi sosial (+). }\end{array}$ \\
\hline
\end{tabular}




\begin{tabular}{|c|c|c|c|}
\hline & & $\begin{array}{l}\text { Diagnosa Keperawatan } \\
\text { Isolasi Sosial } \\
\text { Tindakan Keperawatan } \\
\text { Sp3: } \\
\text { Melatih pasien bercakap- } \\
\text { cakap sambil melakukan } \\
\text { kegiatan harian } \\
\text { Sp4: } \\
\text { Melatih pasien berbicara } \\
\text { sosial: meminta sesuatu, } \\
\text { berbelanja dll. } \\
\text { RTL } \\
\text { Follow up dan Evaluasi SP } \\
\text { 1-SP } 4 \text { Isolasi Sosial }\end{array}$ & $\begin{array}{l}\text { P: } \\
\text { - } \text { Latihan berkenalan dengan } \\
\text { satu orang } 1 \times 1 \text { hari } \\
\text { - Latihan bercakap cakap } \\
\text { sambal melakukan kegaitan } \\
\text { harian } 2 \times 1 \text { hari } \\
\text { - } \\
\text { Latihan berbicara sosial: } \\
\text { meminta sesuatu } 2 \times 1 \text { hari }\end{array}$ \\
\hline $\begin{array}{l}\text { Kamis, } 10 \\
\text { Februari } \\
2022 \\
10.30 \\
\text { WIB }\end{array}$ & & $\begin{array}{l}\text { Data } \\
\text { Tanda dan gejala : } \\
\text { - Pasien mengatakan } \\
\text { berbeda dengan orang } \\
\text { lain } \\
\text { - Pasien tampak lesu } \\
\text { - } \quad \text { Pasien tampak tidak } \\
\text { bergairah } \\
\text { Kemampuan: } \\
\text { - Pasien mampu } \\
\text { berkenalan dengan 1 } \\
\text { orang mampu } \\
\text { - Pasien makn } \\
\text { bercakap-cakap } \\
\text { sambil melakukan } \\
\text { kegiatan harian } \\
\text { Pasien mampu } \\
\text { berbicara sosial: } \\
\text { meminta sesuatu } \\
\text { Diagnosa Keperawatan } \\
\text { Isolasi Sosial } \\
\text { Tindakan Keperawatan } \\
\text { Follow up dan Evaluasi SP } \\
\text { 1 - SP 4 Isolasi Sosial }\end{array}$ & $\begin{array}{l}\text { S : Pasien mengatakan senang } \\
\text { O: } \\
\text { - } \\
\text { Pasien menjelaskan keuntungan } \\
\text { mempunyai teman dan } \\
\text { kerugian tidak mempunyai } \\
\text { teman dengan mandiri } \\
\text { - Pasien mampu berkenalan } \\
\text { dengan 1 orang dengan } \\
\text { mandiri } \\
\text { - Pasien mampu bercakap- } \\
\text { cakap sambal melakukan } \\
\text { kegiatan harian dengan } \\
\text { mandiri } \\
\text { Pasien mampu berbicara } \\
\text { sosial: meminta sesuatu } \\
\text { dengan mandiri } \\
\text { A : Isolasi sosial (+). } \\
\text { P : } \\
\text { Latihan berkenalan dengan } \\
\text { satu orang 1x1 hari } \\
\text { - Latihan bercakap cakap } \\
\text { sambal melakukan kegaitan } \\
\text { harian 2x1 hari } \\
\text { - Latihan berbicara sosial: } \\
\text { meminta sesuatu 2x1 hari }\end{array}$ \\
\hline
\end{tabular}




\begin{tabular}{|c|c|c|}
\hline $\begin{array}{l}\text { Senin, } 14 \\
\text { Februari } \\
2022 \\
15.00 \\
\text { WIB }\end{array}$ & $\begin{array}{l}\text { 1. Data } \\
\text { Tanda dan gejala : } \\
\text { - } \text { Pasien mengatakan } \\
\text { sering mendengar } \\
\text { suara - suara yang } \\
\text { memanggil namanya } \\
\text { namun orangnya tidak } \\
\text { terlihat, suara yang di } \\
\text { dengar mirip sura } \\
\text { ibunya, terdengar 3x } \\
\text { sehari, saat pagi, siang } \\
\text { dan sore, saat dirinya } \\
\text { sendiri dan melamun } \\
\text { suara itu muncul, } \\
\text { dirinya menjadi sedih } \\
\text { dan hanya mampu } \\
\text { menutup telinga saja } \\
\text { saat suara itu muncul. } \\
\text { - Pasien tampak } \\
\text { menutup telinganya } \\
\text { saat suara itu datang } \\
\text { Tindakan keperawatan } \\
\text { Sp1: } \\
\text { - Memanggil namanya } \\
\text { frekuensi, widentifikasi isi, } \\
\text { terjadi, saktu } \\
\text { pencetus, perasaan }\end{array}$ & 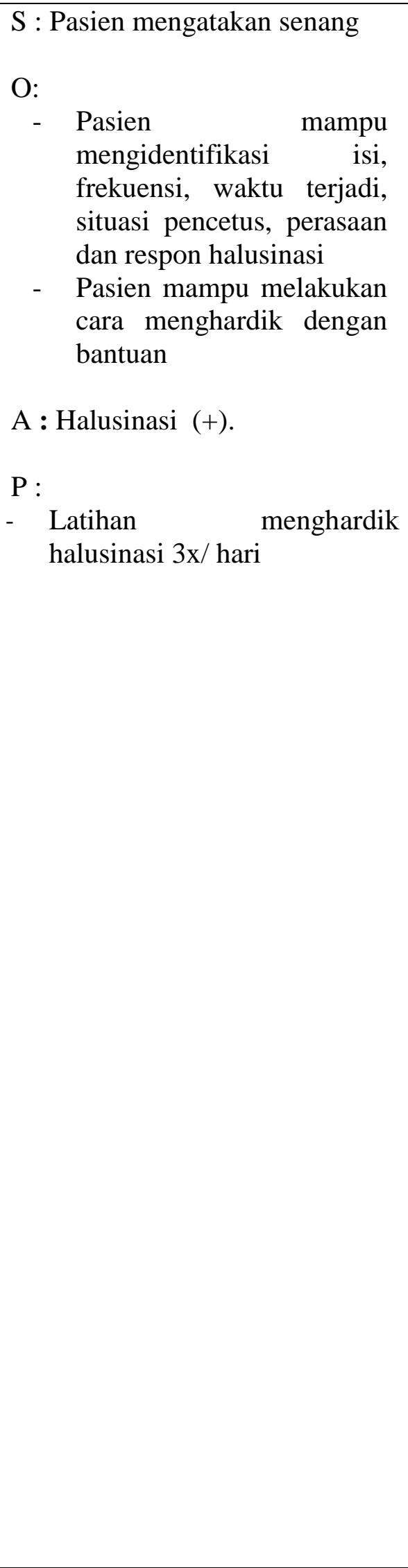 \\
\hline
\end{tabular}




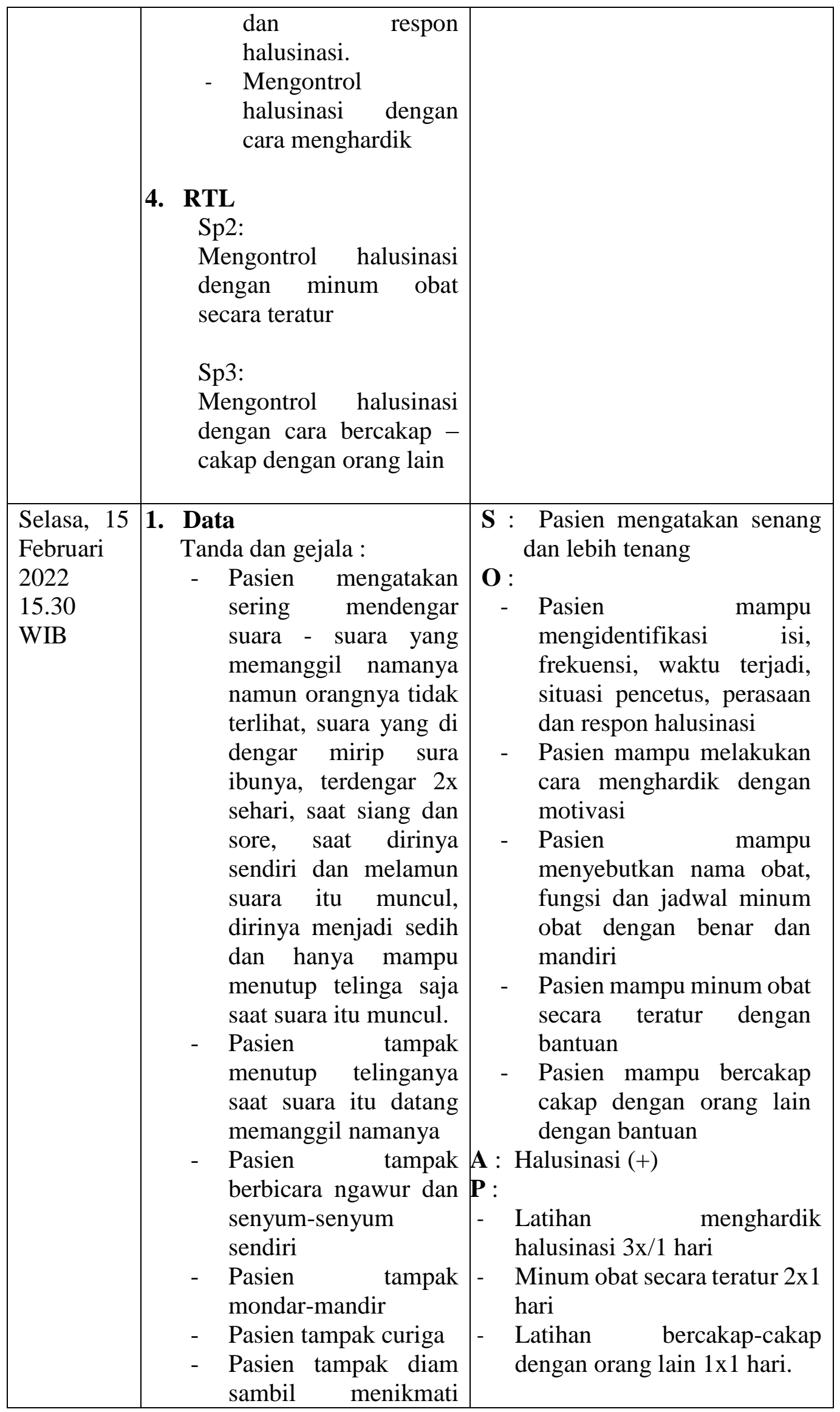




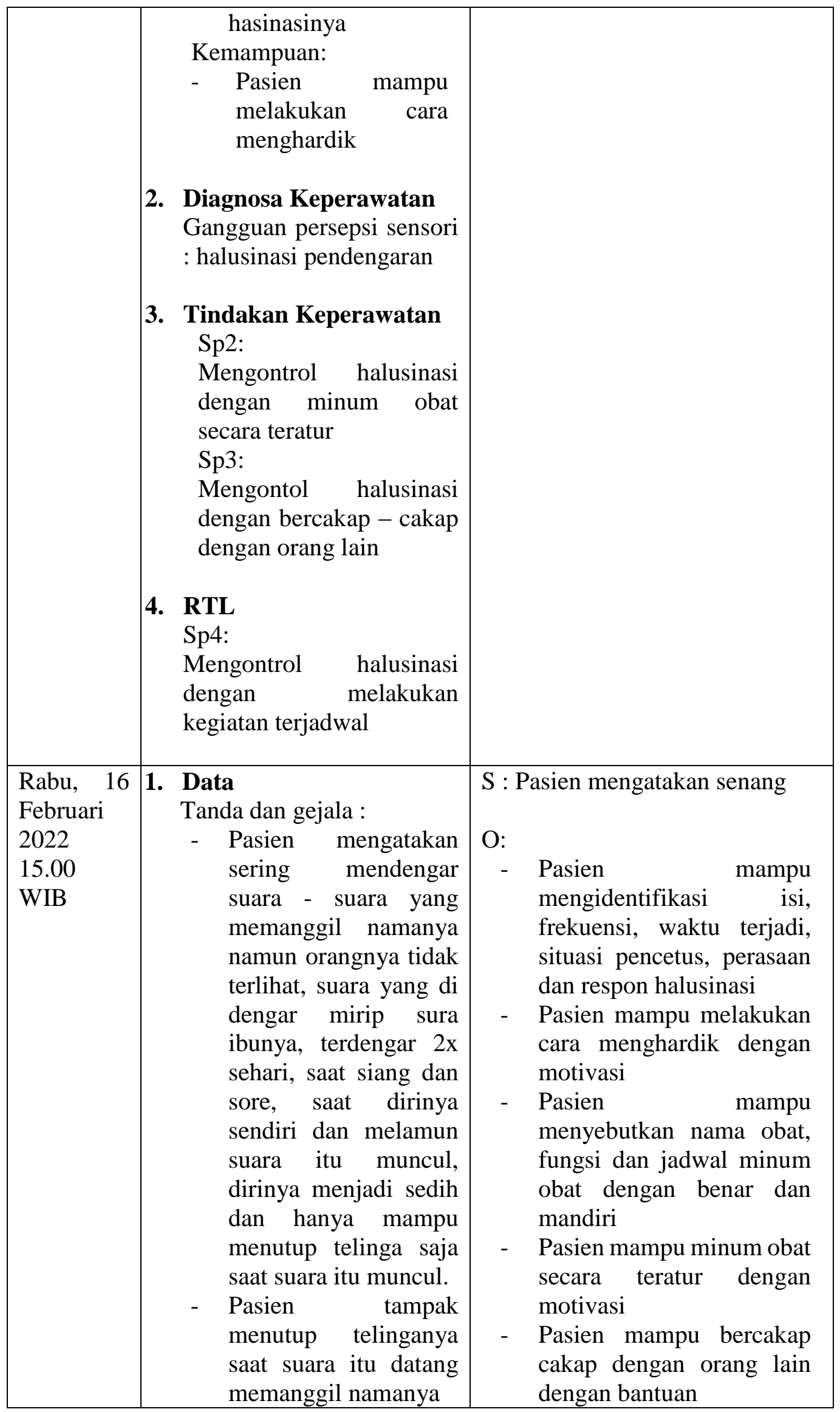




\begin{tabular}{|c|c|c|c|}
\hline & & 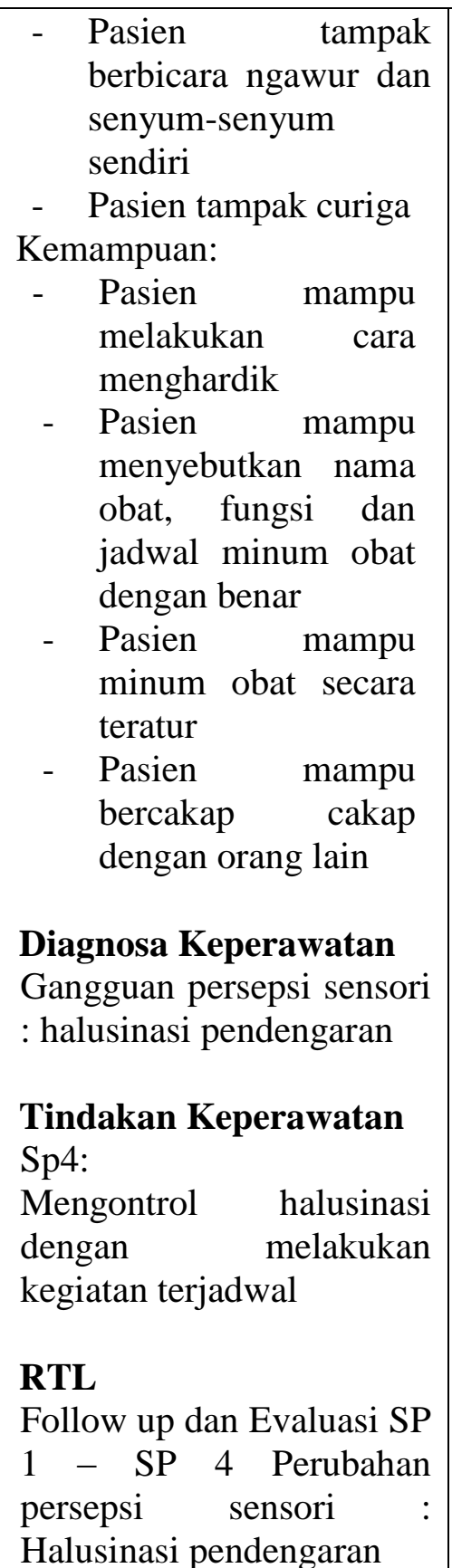 & 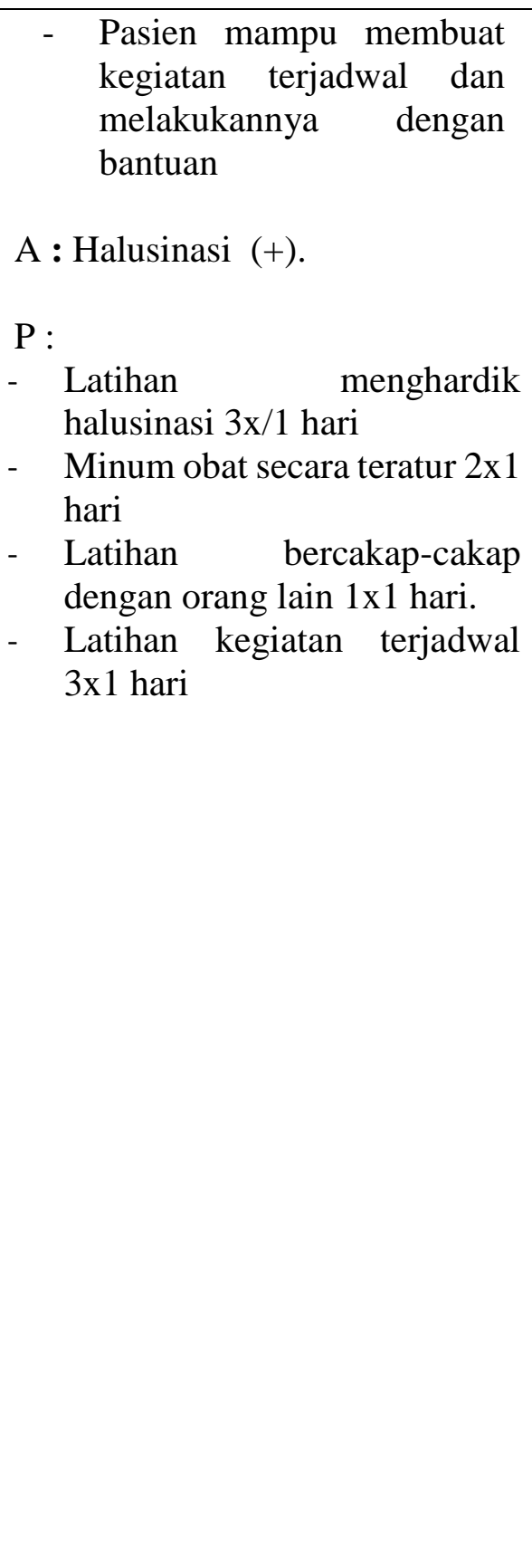 \\
\hline $\begin{array}{l}\text { Kamis, } 17 \\
\text { Februari } \\
2022 \\
16.00 \\
\text { WIB }\end{array}$ & 1. & $\begin{array}{l}\text { Data } \\
\text { Tanda dan gejala : } \\
\text { - Pasien mengatakan } \\
\text { sering mendengar } \\
\text { suara - suara yang } \\
\text { memanggil namanya } \\
\text { namun orangnya tidak } \\
\text { terlihat, suara yang di } \\
\text { dengar mirip sura } \\
\text { ibunya, terdengar 2x } \\
\text { sehari, saat siang dan } \\
\text { sore, saat dirinya }\end{array}$ & $\begin{array}{ll}\text { S : } & \text { Pasien mengatakan senang } \\
& \text { dan tenang } \\
\text { O: } & \\
\text { - } & \text { Pasien } \\
& \text { mengidentifikasi mampu } \\
& \text { frekuensi, waktu terjadi, } \\
& \text { situasi pencetus, perasaan } \\
& \text { dan respon halusinasi } \\
\text { - } & \text { Pasien mampu melakukan } \\
& \text { cara menghardik dengan } \\
& \text { mandiri } \\
\end{array}$ \\
\hline
\end{tabular}




\begin{tabular}{|c|c|}
\hline 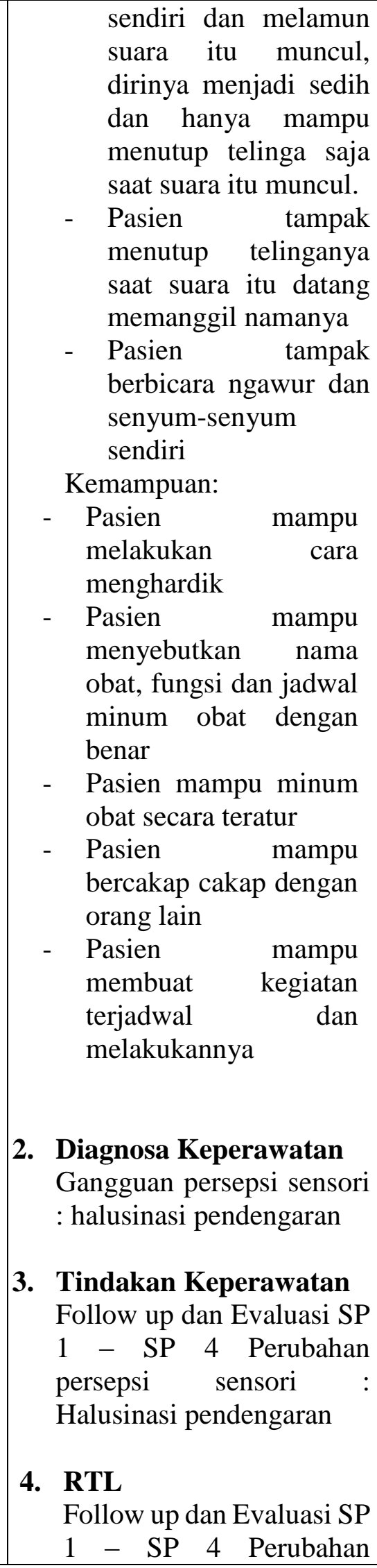 & 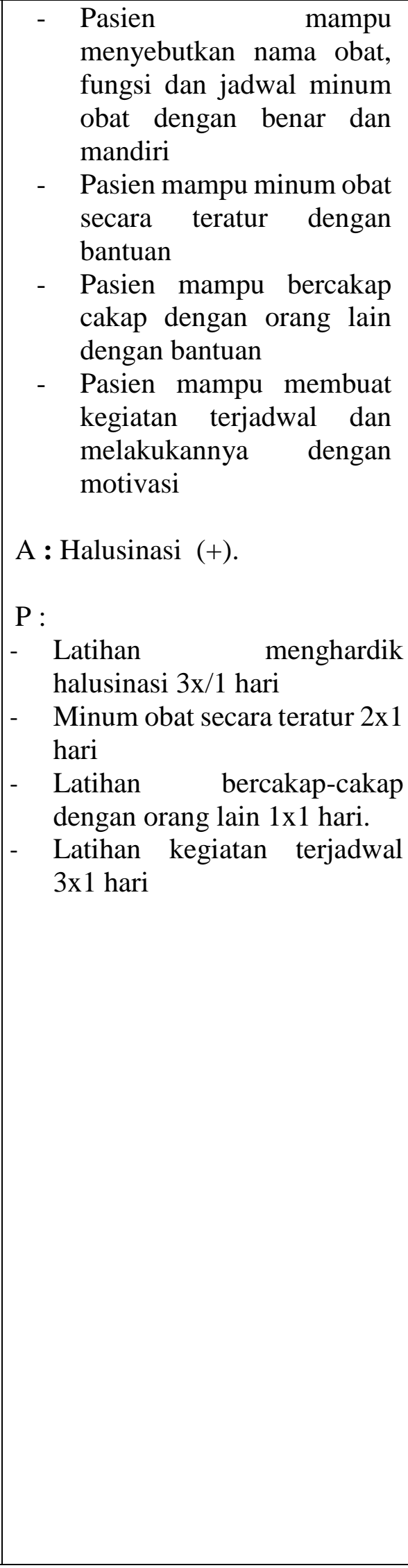 \\
\hline
\end{tabular}




\begin{tabular}{|l|l|l|}
\hline & persepsi sensori : & \\
& Halusinasi pendengaran & \\
\hline
\end{tabular}




\section{BAB 4}

\section{PEMBAHASAN}

Setelah penulis melaksanakan asuhan keperawatan kepada Ny. F dengan Harga Diri Rendah Kronis di Rumah Sakit Jiwa Prof. M Ildrem, maka penulis pada BAB ini akan membahas kesenjangan antara teoritis dengan tinjauan kasus. Pembahasan dimulai melalui tahapan proses keperawatan yaitu pengkajian, diagnosa keparawatan, perencanaan, pelaksanaan dan evaluasi.

\subsection{Tahap Pengkajian}

Selama pengkajian dilakukan pengumpulan data dari beberapa sumber, yaitu dari pasien dan tenaga kesehatan di rumah sakit jiwa. Penulis mendapat sedikit kesulitan dalam menyimpulkan data karena keluarga pasien tidak pernah mengunjungi pasien di rumah sakit jiwa. Maka penulis melakukan pendekatan kepada pasien melalui komunikasi teraupetik yang lebih terbuka membantu pasien untuk memecahkan perasaannya dan juga melakukan observasi kepada pasien. Adapun upaya tersebut yaitu:

1. Melakukan pendekatan dan membina hubungan saling percaya diri pada pasien agar pasien lebih terbuka dan lebih percaya dengan menggunakan perasaan.

2. Mengadakan pengkajian pasien dengan wawancara

3. Mengadakan pengkajian bertanya kepada pegawai rumah sakit jiwa yang ada di ruangan.

Dalam pengkajian ini, penulis tidak menemukan kesenjangan karena ditemukan hal sama seperti diteori: Mengkritik diri sendiri, perasaan tidak mampu, pandangan hidup yang pesimis, penurunan produktivitas, penolakan terhadap kemampuan diri, malu terhadap diri sendiri, bicara ngawur, suka menyendiri, kontak mata kurang (Pardede, 2019).

\subsection{Tahap Diagnosa}

Menurut Kuntari (2019) diagnosa yang berkaitan dengan harga diri rendah yaitu:

1. koping individu nefektif

2. isolasi sosial. 


\section{3. halusinasi}

4. risiko perilaku kekerasan

5. defisit perawatan diri.

Dari hasil pengkajian, terdapat sedikit perbedaan yaitu pasien memiliki masalah keperawatan harga diri rendah kronis, isolasi sosial, dan halusinasi pendengaran.

\subsection{Tahap perencanaan}

Perencanaan dalam proses keperawatan lebih dikenal dengan rencana asuhan keperawatan yang merupakan tahap selanjutnya setelah pangkajian dan penentuan diagnosa keperawatan. Pada tahap perencanaan penulis hanya 
menyusun rencana tindakan keperawatan sesuai dengan pohon masalah keperawatan yaitu : Gangguan Konsep Diri : Harga diri rendah kronis

Pada tahap ini antara tinjauan teoritis dan tinjauan kasus tidak ada kesenjangan sehingga penulis dapat melaksanakan tindakan seoptimal mungkin dan didukung dengan tersedianya sarana ruangan perawat yang baik dan adanya bimbingan dan petunjuk dari petugas kesehatan dari rumah sakit jiwa yang diberikan kepada penulis. Secara teoritis digunakan cara strategi pertemuan sesuai dengan diagnosa keperawatan yang muncul saat pengkajian. Adapun upaya yang dilakukan penulis yaitu :

1. Harga Diri Rendah Kronis

1. Mengidentifikasi kemampuan dan aspek positif yang dimiliki pasien
a. Menilai kemampuan yang dapat digunakan
b. Menetapkan atau memilih kegiatan sesuai kemampuan
c. Melatih kegiatan sesuai kemampuan yang dipilih 1

2. Melatih kegiatan sesuai kemampuan yang dipilih 2

3. Melatih kegiatan sesuai kemampuan yang dipilih 3

4. Mengevalusi jadwal kegiatan harian pasien.

2. Halusinasi

a. Identifikasi isi, frekuensi, waktu terjadi, situasi pencetus, dan respon terhadap halusinasi

b. Mengontrol halusinasi dengan cara menghardik

c. Mengontrol Halusinasi dengan cara minum obat secara teratur

d. Mengontrol halusinasi dengan cara bercakap - cakap dengan orang lain

e. Mengontrol halusinasi dengan cara melakukan aktifitas terjadwal

3. Isolasi Sosial

a. Menjelaskan keuntungan mempunyai teman dan kerugian tidak mempunyai teman.

b. Latih pasien berkenalan dengan dua orang atau lebih

c. Latih pasien bercakap-cakap sambal melakukan kegiatan harian

d. Latih pasienn berbicara social: meminta sesuatu, berbelanja dan sebagainya

Intervensi yang dilakukan mirip dengan intervensi yang ditulis oleh Budi (Keliat, 2020). 


\subsection{Tahap Implementasi}

Pada tahap implementasi mahasiswa hanya mengatasi masalah keperawatan dengan diagnosa keperawatan Gangguan Konsep Diri : Harga diri rendah kronis. Pada diagnosa keperawatan Gangguan Konsep Diri : Harga diri rendah kronis dilakukan strategi pertemuan yaitu mengidentifikasi kemampuan dan aspek positif yang dimiliki pasien, menilai kemampuan yang dapat digunakan menetapkan/ memilih kegiatan sesuai kemampuan "melatih kegiatan sesuai kemampuan yang dipilih 1", melatih kegiatan sesuai kemampuan yang dpilih 2, dan melatih kegiatan sesuai kemampuan yang di pilih 3 (Pardede, Keliat, \& Yulia, 2015).

Strategi pertemuan yang dilakukan untuk masalah halusinasi yaitu mengidentifikasi isi, frekuensi, waktu terjadi, perasaan, respon halusinasi. Kemudian dilakukan latihan mengontrol halusinasi dengan cara menghardik. Pada hari itu juga dijelaskan kepada pasien nama obat, fungsi dan jadwal minum obat, selanjutnya pasien di latih agar minum obat secara teratur. Pertemuan selanjutnya melakukan strategi pelaksanaan mengontrol halusinasi dengan cara bercakap-cakap dengan orang lain dan melatih pasien membuat dan melakukan kegiatan terjadwal. Kegiatan terjadwal yang dibuat yaitu, bangun, mandi, makan, sikat gigi, minum obat, makan siang, tidur siang, makan malam dan minum obat. Tahap terakhir yaitu mengevaluasi kemampuan pasien melakukan Sp1-Sp4.

Strategi pertemuan yang dilakukan untuk masalah isolasi sosial yaitu, menjelaskan keuntungan mempunyai teman dan kerugian tidak mempunyai teman, melatih pasien berkenalan dengan dua orang atau lebih, melatih pasien bercakap-cakap sambal melakukan kegiatan harian, melatih pasienn berbicara social: meminta sesuatu, berbelanja dan sebagainya. Tahap terakhir yaitu mengevaluasi kemampuan pasien melakukan Sp1-Sp4.

\subsection{Tahap evaluasi}


1. Pada tinjauan teoritis evaluasi menurut Keliat (2020) yang diharapkan adalah: Pasien mempercayai perawat sebagai terapis, penurunan tanda dan gejala harga diri rendah kronis dan peningkatan kharga diri pasien Pada tinjauan kasus evaluasi yang didapatkan adalah:

a. Pasien mempercayai perawat sebagai terapis

b. Pasien dapat mengidentifikasi kemampuan dan aspek positif yang dimiliki

c. Pasien mampu menilai kemampuan yang dapat digunakan

d. Pasien mampu menetapkan/ memilih kegiatan sesuai kemampuan "melatih kegiatan sesuai kemampuan yang dipilih 1"

e. Pasien dapat melatih kegiatan sesuai kemampuan yang dpilih 2

f. Pasien dapat melatih kegiatan sesuai kemampuan yang di pilih 3

2. Pada tinjauan teoritis evaluasi menurut Keliat (2020) yang diharapkan adalah: Pasien mempercayai perawat sebagai terapis, penurunan tanda dan gejala halusinasi dan peningkatan kemampuan pasien mengendalikan halusinasi

Pada tinjauan kasus evaluasi yang didapatkan adalah:

a. Pasien mampu mengidentifikasi halusinasinya, seperti halusinasi yang sering dialami pasien yaitu pasien mendengar suara-suara yang mengatakan "andai kau dulu denganku", terjadi dua kali sehari, pada waktu magrib, saat sedang melamun, pasien merasa sedih Karena merasa itu suara mantan kekasihnya, respon pasien setelah mengetahui cara mengontrol halusinasi, pasien mampu mengontrol halusinasi dengan cara menghardik. Pasien sudah tahu bahwa itu tidak nyata karena tidak ada wujudnya.

b. Pasien sudah tahu fungsi obat-obat yang dimakan, pasien menyebutkan nama obat dan waktu minum dengan benar.

c. Pasien mampu melakukan latihan bercakap-cakap dengan orang lain, pasien biasanya bercakap-cakap dengan teman seruangan.

b. Pasien mampu melaksanakan jadwal yang telah dibuat bersama, yang dilakukan pasien yaitu bangun tidur, mandi, makan, dan minum obat 
3. Pada tinjauan teoritis evaluasi menurut Keliat (2020) yang diharapkan adalah: Pasien mempercayai perawat sebagai terapis, penurunan tanda dan gejala isolasi sosial.

Pada tinjauan kasus evaluasi yang didapatkan adalah:

a. Pasien mampu menjelaskan keuntungan mempunyai teman dan kerugian tidak mempunyai teman

b. Pasien mampu berkenalan dengan 1 orang

c. Pasien mampu bercakap-cakap sambal melakukan kegiatan harian

d. Pasien mampu berbicara sosial: meminta sesuatu 


\section{BAB 5}

\section{PENUTUP}

\subsection{Kesimpulan}

Setelah menguraikan tentang proses keperawatan pada Ny.F penulis melanjutkan asuhan keperawatan pada pasien dengan Harga Diri Rendah Kronis di ruang mawar, Maka perlu mengambil kesimpulan untuk meningkatkan mutu asuhan keperawatan yang telah ada :

1. Pengkajian yang dilaksanakan tidak banyak berbeda dengan pengkajian teoritis maupun penulis, tidak terdapat kesulitan dalam pengkajian pasien. Didapatkan pasien Ny. F usia 27 tahun beragama Islam. Pasien mengatakan merasa tidak dihargai dan pasien merasa tidak berguna, mengatakan merasa minder dan malu karena tidak bisa melakukan apapun dalam hidupnya, malu karena masuk rumah sakit jiwa, merasa tidak mampu menjadi ibu yang baik karena takut anaknya diejek anak orang gila, ingin sendiri, berbeda dengan orang lain, sering mendengar suara - suara yang memanggil namanya namun orangnya tidak terlihat, suara yang di dengar mirip sura ibunya, terdengar 3x sehari, saat pagi, siang dan sore, saat dirinya sendiri dan melamun, suara itu muncul, dirinya menjadi sedih dan hanya mampu menutup telinga saja saat suara itu muncul.

2. Dari hasil pengkajian dibuat analisa data untuk menentukan masalah keperawatan. Masalah keperawatan yaitu, harga diri rendah kronis, isolasi sosial dan halusinasi pendengaran.

3. Intervensi yang disusun berdasarkan masalah keperawatan yang sudah ditegakkan. Hal ini dilakukan bentuk usaha mengatasi masalah yang dihadapi pasien, penulis menyusun rencana tindakan keperawatan sesuai dengan teoritis begitu juga dengan strategi pelaksanaan.

4. Dalam pelaksanaan tindakan keperawatan disesuaikan dengan perencanaan dan dapat dilaksanakan walaupun belum optimal.

5. Pada tahap evaluasi terhadap tindakan keperawatan masalah yang dihadapi pasien tidak teratasi semua sesuai dengan masalah pasien.

\subsection{Saran}

1. Bagi Mahasiswa

Hendaknya mahasiswa/i dapat melakukan asuhan keperawatan sesuai dengan tahapan-tahapan dengan baik dan benar yang diperoleh selama masa pendidikan baik diakademik maupun dilapangan praktek.

2. Bagi Pasien 
Diharapkan pasien dapat menerapkan terapi yang telah diberikan baik secara medik maupun terapi keperawatan yang telah diajarkan demi percepatan penyembuhan penyakit dengan masalah gangguan jiwa.

3. Bagi Perawat

Diharapkan dapat menerapkan komunikasi terapeutik dalam pelaksanaan strategi pertemuan 1-4 pada pasien dengan harga diri rendah kronik sehingga dapat mempercepat proses pemulihan pasien.

4. Bagi keluarga

Agar keluarga selalu memberikan motivasi kepada pasien dan juga perawatan harga diri rendah kronik pendengaran dirumah.

5. Bagi Institusi Pendidikan

Dapat meningkatkan bimbingan klinik kepada mahasiswa profesi ners sehingga mahasiswa semakin mampu dalam melakukan asuhan keperawatan pada pasien-pasien yang mengalami harga diri rendah kronik.

6. Bagi Rumah Sakit

Laporan ini diharapkan dapat menjadai acuan dan referensi dalam memberikan asuhan keperawatan pada pasien dengan harga diri rendah kronik. 


\section{DAFTAR PUSTAKA}

Andri, J., Febriawati, H., Panzilion, P., Sari, S. N., \& Utama, D. A. (2019). Implementasi keperawatan dengan pengendalian diri pasien halusinasi pada pasien skizofrenia. Jurnal Kesmas Asclepius, 1(2), 146-155 https://doi.org/10.31539/jka.v1i2.922

Atmojo, B. S. R., \& Purbaningrum, M. A. (2021). Literature Review: Penerapan Latihan Kemampuan Positif Terhadap Peningkatan Harga Diri Rendah Pada Pasien Yang Mengalami Skizofrenia Dengan Gangguan Konsep Diri Harga Diri Rendah. Nursing Science Journal (NSJ), 2(1), 55-62. https://doi.org/10.53510/nsj.v2i1.63

Diana Putri, K. R. I. S. M. O. N. I. T. A. (2020). Asuhan Keperawatan Pada Pasien Skizofrenia Dengan Masalah Keperawatan Harga Diri Rendah Kronis Di Rumah Sakit Jiwa Dr. Arif Zainudin Surakarta (Doctoral Dissertation, Universitas Muhammadiyah Ponorogo).

Dwi Saptina, C. H. A. N. D. R. A. (2020). Asuhan Keperawatan Pada Pasien Skizofrenia Dengan Masalah Harga Diri Rendah Kronik(Doctoral Dissertation, Universitas Muhammadiyah Ponorogo).

Fajarani, A. S. (2017). Tingkat stres dan harga diri narapidana wanita di lembaga pemasyarakatan kelas II A Kota Bogor. Jurnal Riset Kesehatan Poltekkes Depkes Bandung, 9(2), 26-33. https://doi.org/10.34011/juriskesbdg.v9i2.288

Febrina. (2018). “Asuhan Keperawatan Jiwa Pada Keluarga Dengan Harga Diri Rendah Kronis di Wilayah Kerja Puskesmas Nanggalo Kota Padang” Poltekkes Kemenkes Padang, xi + 63 halaman.

Irawati, K., Daulima, N. H. C., \& Wardhani, I. Y. (2019). Manajemen Kasus Pada Pasien Harga Diri Rendah Kronis Dengan Pendekatan Teori Caring. Jurnal Keperawatan, 11(2), 125-134. https://doi.org/10.32583/keperawatan.v11i2.486

Keliat, Budi Anna, dkk. 2020. Asuhan Keperawatan Jiwa. Jakarta: EGC

Kuntari, M., \& Nyumirah, S. (2019). Asuhan Keperawatan Pada Tn. N Dengan Gangguan Konsep Diri: Harga Diri Rendah. Buletin Kesehatan: Publikasi Ilmiah Bidang kesehatan, 3(1), 26-40.

Pardede, J. A., \& Hasibuan, E. K. (2019). Dukungan Caregiver Dengan Frekuensi Kekambuhan Pasien Skizofrenia. Idea Nursing Journal, 10(2). https://doi.org/10.52199/inj.v10i2.17161

Pardede, J. A., \& Laia, B. (2020). Decreasing Symptoms of Risk of Violent Behavior in Schizophrenia Patients Through Group Activity Therapy. Jurnal 
Ilmu Keperawatan Jiwa, 3(3), 291-300. http://dx.doi.org/10.32584/jikj.v3i3.621

Pardede, J. A., Damanik, R. K., Simanullang, R. H., \& Sitanggang, R (2020). The Effect Of Cognitive Therapy On Changes In Self-Esteem On Schizophrenia Patients. European Journal of Molecular \& Clinical Medicine, 7(11).

Pardede, J. A., Harjuliska, H., \& Ramadia, A. (2021). Self-Efficacy dan Peran Keluarga Berhubungan dengan Frekuensi Kekambuhan Pasien Skizofrenia. Jurnal Ilmu Keperawatan Jiwa,4(1), 57-66. http://dx.doi.org/10.32584/jikj.v4i1.846

Pardede, J. A. (2020). Decreasing Hallucination Response Through Perception Stimulation Group Activity Therapy In Schizophrenia Patients. Iar Journal of Medical Sciences, 1(6), 304-309.

Pardede, J. A. (2019). Health Education Of Drinking Medication Adherence On Schizophrenia Patients. Journal Of Psychiatry, 2(2), 723.

Pardede, J. A., Keliat, B. A., \& Yulia, I. (2015). Kepatuhan Dan Komitmen Pasien Skizofrenia Meningkat Setelah Diberikan Acceptance And Commitment Therapy Dan Pendidikan Kesehatan Kepatuhan Minum Obat. Jurnal Keperawatan Indonesia, 18(3), 157-166. https://doi.org/10.7454/jki.v18i3.419

Purwasih, R., \& Susilowati, Y. (2016). Penatalaksanaan Pasien Gangguan Jiwa Dengan Gangguan Konsep Diri: Harga Diri Rendah Di Ruang Gathotkoco Rsjd Dr. Amino Gondohutomo Semarang. Jurnal Profesi Keperawatan (JPK), 3(2).

Rahayu, S., Mustikasari, M., \& Daulima, N. H. (2019). Perubahan Tanda Gejala dan Kemampuan Pasien Harga Diri Rendah Kronis Setelah Latihan Terapi Kognitif dan Psikoedukasi Keluarga. Journal Educational Of Nursing (JEN), 2(1), 39-51. https://doi.org/10.37430/jen.v2i1.10

Rahmawati, A. N., Ramadhani, A. S., \& Apriliyani, I. (2021). Studi Kasus Harga Diri Rendah Kronis Pada Pasien Skizofrenia. Jurnal Keperawatan Notokusumo, 9(2), 13-23.

Rahmawati, E. D. (2019). Asuhan Keperawatan Pada Pasien Skizofrenia Residual Dengan Masalah Harga Diri Rendah Kronik Di Rumah Sakit Jiwa Daerah Dr. Arif Zainudin Surakarta (Doctoral Dissertation, Universitas Muhammadiyah Ponorogo).

Riset Kesehatan Dasar (RISKESDAS). (2018). Kementrian Kesehatan Badan Penelitian dan Pengembangan Kesehatan 
Rokhimmah, Y., \& Rahayu, D. A. (2020). Penurunan Harga Diri Rendah Dengan Menggunakan Penerapan Terapi Okupasi (Berkebun). Ners Muda, 1(1), 1822. https://doi.org/10.26714/Nm.V1i1.5493

Safitri, A. (2020). Studi Literatur: Asuhan Keperawatan Keluarga Penderita Skizofrenia Dengan Gangguan Konsep Diri: Harga Diri Rendah Kronis (Doctoral dissertation, Universitas Muhammadiyah Ponorogo).

Sitorus, C. (2019). Pengkajian Klasifikasi Data Dalam Proses Keperawatan.

Stuart, G. W. (2016). Prinsip dan Praktek Keperawatan Kesehatan Jiwa Stuart. 1 Indonesia Edition, by Budi Anna Keliat and Jesika Pasaribu. Singapore: Elsevier.

Tuasikal, H., Siauta, M., \& Embuai, S. (2019). Upaya Peningkatan Harga Diri Rendah Dengan Terapi Aktivitas Kelompok (Stimulasi Persepsi) di Ruang Asoka (Sub Akut Laki) RSKD Provinsi Maluku. Window of Health: Jurnal Kesehatan, 345-351.

WHO. (2019). Mental Disorders. https://www.who.int/news-room/factsheets/detail/mental-disorders

WHO, (2022). Schizophrenia. https://www.who.int/news-room/factsheets/detail/schizophrenia

Widianti, E., Keliat, B. A., \& Wardhani, I. Y. (2017). Aplikasi Terapi Spesialis Keperawatan Jiwa pada Pasien Skizofrenia dengan Harga Diri Rendah Kronis di RSMM Jawa Barat. Jurnal Pendidikan Keperawatan Indonesia, 3(1), 83-99.https://doi.org/10.17509/jpki.v3i1.7489.

Wijayati, F., Nasir, T., Hadi, I., \& Akhmad, A. (2020). Faktor-faktor yang berhubungan dengan kejadian harga diri rendah pasien gangguan jiwa. Health Information: Jurnal Penelitian, 12(2), 224-235. https://doi.org/10.36990/hijp.v12i2.234 